\title{
If You Can't Stand the Heat, Get Out of the Drug Business: Thermal Imagers, Emerging Technologies, and the Fourth Amendment
}

\author{
Jonathan Todd Laba $\dagger$
}

\section{TABLE OF CONTENTS}

Introduction.

I. A Hot Topic: Thermal Imagers in Practice .............................. 1449

II. Katz \& Co.: A Foundation Under Attack................................ 1452

A. The Revolution of Katz .................................................. 1452

B. The Promise of Katz Denied..............................................1454

1. The First Blow: Smith v. Maryland ................................ 1454

2. More Restrictions: A Fourth Amendment in Big Brother's Clothing................................................. 1456

3. Further Intrusions Allowed: What's All This Garbage?. 1460

III. Thermal Imagery: The Latest Challenge..................................... 1462

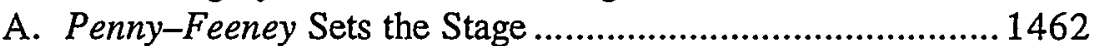

B. Criticism of the Penny-Feeney Decision ............................ 1465

1. The Assumption That FLIRs Are a Nonintrusive

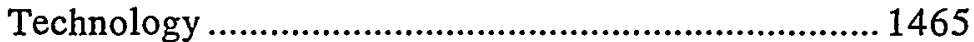

2. The "Heat Waste" Analogy........................................... 1467

3. The "Dog Sniff" Analogy.......................................... 1468

IV. Fourth Amendment Values and the Use of Technology in

Law Enforcement: A Double-Edged Sword............................. 1470

V. Guideposts for the Court: Evaluating Emerging Technologies

Under the Court's Privacy Framework ......................................1475

A. The Area Subject To Surveillance ..................................... 1476

B. The Nature of the Information Disclosed to the Police ....... 1478

Copyright (C) 1996 California Law Review, Inc.

$\dagger$ B.A. 1989, University of Virginia; J.D. 1996, Boalt Hall School of Law, University of California, Berkeley. This Comment is dedicated to my mother, Sandra Laba, whose wisdom, guidance and love will always remain with me. I thank Professor Rachel Moran for her insightful comments and criticism; Jennifer Berman for a terrific editing job; and the editors and staff of the California Law Review for their tremendous efforts. Remaining mistakes or omissions are my own. For their unwavering support and encouragement, my profound gratitude goes to my father, Marvin Laba, my brother, Stuart Laba, my aunt, Jean Seltzer, and my partner and best friend, Dorilyn Ahana. 
C. Public Awareness of Law Enforcement Technologies......... 1480

D. The Degree of Intrusion................................................... 1483

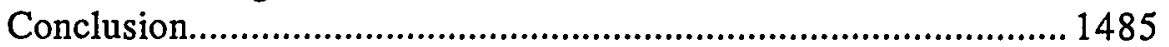




\title{
If You Can't Stand the Heat, Get Out of the Drug Business: Thermal Imagers, Emerging Technologies, and the Fourth Amendment
}

\author{
Jonathan Todd Laba
}

In recent years, law enforcement authorities have increasingly used thermal imaging devices to search for evidence of indoor marijuana cultivation. These devices are able to detect such evidence without requiring officers to enter the building under investigation. Several appellate courts have held that the use of these imaging devices does not constitute a "search" under the Fourth Amendment, and therefore that authorities need not obtain a warrant before using one. The author argues that the thermal imaging issue reflects wider questions concerning the increasing use of high technology in criminal investigation. By approving the warrantless use of thermal imagers, the author claims, courts have opened the door to countless other invasive, unregulated uses of technology. As a remedy, the author proposes four criteria that courts ought to consider in evaluating whether the use of a particular technology constitutes a search under the Fourth Amendment. These criteria are: the area that is subject to surveillance, the nature of the information the technology can disclose, the degree of public awareness of the technology, and the degree of intrusion into individuals' private lives that the technology allows. By analyzing these four criteria in the thermal imaging context, the author demonstrates how they would provide more protection for privacy than the analysis that courts have used previously, while still allowing law enforcement authorities to investigate criminal activity aggressively and effectively.

Electronic surveillance ... makes the police omniscient; and police omniscience is one of the most effective tools of tyranny. ${ }^{1}$

1. Lopez v. United States, 373 U.S. 427, 466 (1963) (Brennan, J., dissenting). 


\section{INTRODUCTION}

Rarely has a topic swept through the courts with the frenetic speed of the thermal imaging debate. The constitutionality of thermal imagers-heat-measuring devices used by law enforcement agents to detect marijuana growing operations-had not been considered by any court prior to 1991. In the past five years, however, at least four federal courts of appeals and four district courts have decided whether the use of these devices constitutes a Fourth Amendment "search" requiring a warrant for their use. ${ }^{3}$ A number of state courts have reached the issue as well. ${ }^{4}$ Four additional circuits, confronted with the question, have declined to decide the issue. ${ }^{5}$

Remarkably, legal commentary has managed to keep pace with this jurisprudential flood. One journal article and a substantial number of student comments and casenotes have evaluated these decisions since

\section{The Fourth Amendment to the United States Constitution provides:}

The right of the people to be secure in their persons, houses, papers and effects, against unreasonable searches and seizures, shall not be violated, and no Warrants shall issue, but upon probable cause, supported by Oath or affirmation, and particularly describing the place to be searched, and the persons or things to be seized.

U.S. ConsT. amend. IV.

3. United States v. Ishmael, 48 F.3d 850 (5th Cir.) (holding the use of thermal imagers not to constitute a Fourth Amendment search), cert. denied, 116 S. Ct. 74 (1995); United States v. Myers, 46 F.3d 668 (7th Cir.) (not a search), cert. denied, 116 S. Ct. 213 (1995); United States v. Ford, 34 F.3d 992 (11th Cir. 1994) (not a search); United States v. Pinson, 24 F.3d 1056 (8th Cir.) (not a search), cert. denied, 115 S. Ct. 664 (1994); United States v. Domitrovich, 852 F. Supp. 1460 (E.D. Wash. 1994) (not a search), aff'd on other grounds, 57 F.3d 1078 (9th Cir. 1995); United States v. Kyllo, 809 F. Supp. 787 (D. Or. 1992) (not a search), aff'd in part and vacated in part, 37 F.3d 526 (9th Cir. 1994), on remand, No. CR. 92-51-FR, 1996 WL 125594 (reaffirming not a search); United States v. Penny-Feeney, 773 F. Supp. 220 (D. Haw. 1991) (not a search), affd on other grounds sub nom. United States v. Feeney, 984 F.2d 1053 (9th Cir. 1993). But see United States v. Field, 855 F. Supp. 1518 (W.D. Wis. 1994) (search).

4. See, e.g., State v. Cramer, 851 P.2d 147 (Ariz. Ct. App. 1992) (not a search); LaFollette v. Kentucky, 91 S.W.2d 747 (Ky. 1996) (not a search); State v. Niel, 671 So.2d 1111 (La. Ct. App. 1996) (not a search); State v. McKee, 510 N.W.2d 807 (Wis. Ct. App. 1993) (not a search). But see People v. Deutsch, 52 Cal. Rptr. 2d 366 (Cal. Ct. App. 1996) (search); State v. Young, 867 P.2d 593 (Wash. 1994) (search).

5. See United States v. Cusumano, 67 F.3d 1497 (10th Cir. 1995) (holding the use of thermal imagers to constitute a Fourth Amendment search), vacated on reh'g en banc, 83 F.3d 1247 (10th Cir. 1996) (vacating panel opinion, declining to reach FLIR issue, and holding other information in warrant sufficient to provide probable cause); United States v. Kyllo, 37 F.3d 526 (9th Cir. 1994) (remanding for factual inquiry into technological capabilities of thermal imagers); United States v. Zimmer, 14 F.3d 286 (6th Cir. 1994) (noting that thermal information and other evidence were sufficient to establish probable cause, but not considering whether device itself constituted a search); United States v. Deaner, 1 F.3d 192 (3d Cir. 1993) (holding evidence independent of the thermal information sufficient to establish probable cause); United States v. Feeney, 984 F.2d 1053 (9th Cir. 1993) (same). See also United States v. Casanova, 835 F. Supp. 702 (N.D.N.Y. 1993) (holding other evidence sufficient to support probable cause without exploring constitutionality of warrantless use of thermal imager). 
1993. ${ }^{6}$ The four federal courts of appeals that had addressed the question prior to October 1995 each had held that the use of thermal imagers did not constitute a Fourth Amendment "search," thereby sanctioning police use of this technology without the familiar constraints of the Fourth Amendment's warrant requirement. Most law review commentators have sharply criticized this holding, as well as the Supreme Court's underlying Fourth Amendment jurisprudence relied on by the various courts of appeals in each case. ${ }^{8}$

6. See, e.g., Lisa J. Steele, Waste Heat and Garbage: The Legalization of Warrantless Infrared Searches, 29 CRIM. L. BuLl. 19 (1993); Michael A. De Vito \& Stuart M. Flamen, Note, "FLIR"ting with Danger: A Fourth Amendment Analysis of Infrared Imaging, 10 ST. JOHN's J. LEGAL COMMENT. 651 (1995); Melinda Foster, Note, State v. Young: A Cool View Toward Infrared Thermal-Detection Devices, 30 Gonz. L. Rev. 135 (1994/95); Robert K. Glinski, Note, Thermal Imagery and the Fourth Amendment: Do I Look Warm To You?-United States v. Ford, 14 TEMP. ENvTL. L. \& TECH. J. 293 (1995); Lisa T. Hale, Comment, United States v. Ford: The Eleventh Circuit Permits Unrestricted Police Use of Thermal Surveillance on Private Property Without a Warrant, 29 GA. L. Rev. 819 (1995); Michael L. Huskins, Comment, Marijuana Hot Spots: Infrared Imaging and the Fourth Amendment, 63 U. CHI. L. REv. 655 (1996); Ralph Janzen, Comment, United States v. Field: Infrared Scans; Curbing Potential Privacy Invasions, 69 ST. JoHN's L. Rev. 633 (1995); Gregory L. Kelley, Comment, The Warrantless Use of Thermal Imagery, 12 T.M. COOLEY L. REv. 597 (1995); M. Annette Lanning, Note, Thermal Surveillance: Do Infrared Eyes in the Sky Violate the Fourth Amendment?, 52 WASH. \& LEE L. Rev. 1771 (1995); Susan Moore, Note and Comment, Does Heat Emanate Beyond the Threshold?: Home Infrared Emissions, Remote Sensing, and the Fourth Amendment Threshold, 70 CHI.-KENT L. REv. 803 (1994); Michael D. O’Mara, Comment, Thermal Surveillance and the Fourth Amendment: Heating Up the War On Drugs, 100 Dick. L. REv. 415 (1996); Bradley J. Plaschke, Comment, United States v. Deaner: Thermal Imagery, The Lotest Assault on the Fourth Amendment Right to Privacy, 12 J. MARSHALL J. COMPUTER \& INFo. L. 607 (1994); Lynne M. Pochurek, Note and Comment, From the Battlefront to the Homefront: Infrared Surveillance and the War on Drugs Place Privacy Under Siege, 7 ST. Thomas L. Rev. 137 (1994); Daniel J. Polatsek, Note, Thermal Imaging and the Fourth Amendment: Pushing the Katz Test Toward Terminal Velocity, 13 J. MARSHALl J. COMPUTER \& INFo. L. 453 (1995); Jeffrey J. SkeIton, Note, Infrared Imaging Technology: Threatening to See Through the Fourth Amendment, 29 IND. L. REv. 231 (1995); Scott J. Smith, Note, Thermal Surveillance and the Extraordinary Device Exception: ReDefining the Scope of the Katz Analysis, 30 VAL. U. L. REv. 1071 (1996); Tracy M. White, Note, The Heat Is On: The Warrantless Use of Infrared Surveillance to Detect Indoor Marijuana Cultivation, 27 ARIZ. ST. LJ. 295 (1995); Mindy G. Wilson, Note, The Prewarrant Use of Thermal Imagery: Has This Technological Advance in the War Against Drugs Come at the Expense of Fourth Amendment Protections Against Unreasonable Searches?, 83 KY. LJ. 891 (1994-95); Matthew L. Zabel, Comment, A High-Tech Assault on the "Castle": Warrantless Thermal Surveillance of Private Residences and the Fourth Amendment, 90 Nw. U. L. REv. 267 (1995).

7. United States v. Ishmael, 48 F.3d 850 (5th Cir.), cert. denied, 116 S. Ct. 74 (1995); United States v. Myers, 46 F.3d 668 (7th Cir.), cert. denied, 116 S. Ct. 213 (1995); United States v. Ford, 34 F.3d 992 (11th Cir. 1994); United States v. Pinson, 24 F.3d 1056 (8th Cir.), cert. denied, 115 S. Ct. 664 (1994).

8. See, e.g., Hale, supra note 6; Moore, supra note 6; Pochurek, supra note 6; Polatsek, supra note 6. To be sure, not all commentators have criticized the Supreme Court's Fourth Amendment case law; several have merely applied the Court's Fourth Amendment jurisprudence to thermal imaging devices, without inquiring whether those Supreme Court cases were correctly decided. See, e.g., Foster, supra note 6, at 154-61 (arguing that the Washington Supreme Court's holding that the use of thermal imagers constituted a Fourth Amendment search was inconsistent with relevant United States Supreme Court precedent); White, supra note 6, at 308 (arguing that the Eighth Circuit holding in United States v. Pinson was consistent with Supreme Court precedent in lolding that the use of thermal imagers did not constitute a searcli). 
The Supreme Court, however, apparently has not shared the concerns raised by these authors, and has denied certiorari in each case in which petitions have been filed. ${ }^{9}$ The Justices, however, may soon be forced to confront the issue. In October 1995, a Tenth Circuit panel decided, contrary to the positions taken by the Fifth, Seventh, Eighth, and Eleventh Circuits, that the use of thermal imaging devices constitutes a "search" under the Fourth Amendment." short-lived; upon rehearing en banc, the circuit vacated the panel opinion and declined to take a position on the thermal imaging question at all. Nonetheless, the panel opinion's thoughtful analysis (repeated nearly in its entirety in the dissent to the en banc opinion $)^{11}$ provides a healthy intellectual counterweight to the mass of published opinions holding that the use of thermal imagers does not implicate the Fourth Amendment. With two-thirds of the circuits yet to decide the issue, it seems likely that a circuit split will re-emerge in the near future.

Thermal imaging devices, also known as Forward Looking Infrared Devices, or FLIRs, are frequently used for the detection of indoor marijuana growing operations. Marijuana cultivators increasingly are moving their operations indoors, both to shield their activities from the public and to avoid being dependent on favorable weather for successful crops. These indoor marijuana "grows" require powerful heat lamps for the marijuana to flourish. Buildings housing marijuana "grows" thus are significantly warmer than typical occupied households. Thermal imaging devices, which detect differences in surface temperature among neighboring objects, can reveal disproportionately warm interiors from outside the structures. By directing one of these devices at a home, barn, shed, or garage, law enforcement agents can obtain thermal information to help establish probable cause for a search warrant.

The debate over the use of thermal imagers transcends the narrow question regarding the utility, invasiveness, and Fourth Amendment implications of the devices themselves. Rather, the debate has raised much broader questions concerning the intersection of technology and the Fourth Amendment. As we all know, technology is, for the most part, a good thing: it has provided us with microwave ovens, VCRs, portable computers, and cordless phones. What many people only vaguely perceive-particularly those who have never crossed paths with the criminal justice system-is the degree to which technology may represent an invasive, even threatening, force in our lives.

9. See supra note 3 .

10. United States v. Cusumano, 67 F.3d 1497 (10th Cir. 1995), vacated on reh'g en banc, 83 F.3d 1247 (10th Cir. 1996).

11. United States v. Cusumano, 83 F.3d 1247, 1251 (10th Cir. 1996) (McKay, J., dissenting). 
Although the controversy over thermal imagers was launched in the courts only four years ago in United States $v$. Penny-Feeney, ${ }^{12}$ the tension between technology and the Fourth Amendment is hardly new. In 1927, the Supreme Court held that the use of a searchlight to illuminate the deck of a ship carrying illicit liquor was not a search under the Fourth Amendment. ${ }^{13}$ The following year, the Court held in Olmstead $v$. United States ${ }^{14}$ that a telephone wiretap did not constitute a search because there was no physical invasion or trespass of the defendants' persons, houses, papers, or effects. ${ }^{15}$

This property-based notion of the Fourth Amendment, which presumed that physical intrusion was necessary to show a Fourth Amendment violation, survived until the 1967 decision of Katz v. United States. ${ }^{16}$ In Katz, the Court again confronted the question of whether a wiretap constitutes a search. Recognizing that the property/trespass framework was inadequate to deal with the constitutional demands of modern technology, the Court held that the Fourth Amendment protects people, and not simply areas, against unreasonable searches and seizures. ${ }^{17}$ In a now-famous concurrence, Justice Harlan wrote that a government action is a "search" if (1) the person has exhibited an actual expectation of privacy (the "subjective" prong), and (2) that expectation is one society recognizes as reasonable (the "objective" prong). ${ }^{18}$ This two-part test has been adopted by the Court as the framework under which it evaluates whether a government activity constitutes a "search."

Since Katz was decided, various state and federal courts have grappled with an array of law enforcement tools that have afforded increasingly troublesome opportunities for police intrusion into our private lives. Among other things, these cases have evaluated the use of tracking devices, aerial mapping cameras, phone company "pen registers," helicopter overflights, and the monitoring of cordless phone conversations. ${ }^{20}$ These courts uniformly have applied Katz's two-step

12. 773 F. Supp. 220 (D. Haw. 1991), aff'd on other grounds sub nom. United States v. Feeney, 984 F.2d 1053 (9th Cir. 1993). See infra Part III for a full discussion of Penny-Feeney and its progeny.

13. United States v. Lee, 274 U.S. 559, 563 (1927).

14. 277 U.S. 438 (1928).

15. Id. at $465-66$; see also infra notes $65-68$ and accompanying text (describing the facts and reasoning of Olmstead).

16. 389 U.S. 347 (1967).

17. Id. at 353 .

18. Id. at 361 (Harlan, J., concurring). See also infra notes 65-80 and accompanying text (describing the impact of Katz on Fourth Amendment jurisprudence). test).

19. See, e.g., Smith v. Maryland, 442 U.S. 735, 740 (1979) (adopting Justice Harlan's two-part

20. See, e.g., Florida v. Riley, 488 U.S. 445 (1989) (naked-eye observation of greenhouse from low-flying helicopter); California v. Greenwood, 486 U.S. 35 (1988) (search of trash placed for 
"expectation of privacy" test to determine whether the Fourth Amendment is even implicated in the government conduct at issue-in other words, whether the relevant activity constitutes a Fourth Amendment "search." With the Supreme Court leading the charge, ${ }^{21}$ these courts have dramatically loosened Fourth Amendment guarantees by holding that many invasive governinent investigatory techniques do not constitute searches. ${ }^{22}$ Consequently, since Fourth Amendment safeguards do not govern those activities, government officials may freely use those techniques to compile information about any individual, at any time. ${ }^{23}$

The Court's loosening of Fourth Amendment guarantees during the past twenty years is motivated, in part, by spiraling crime statistics, which in turn have directly resulted from the explosion in the drug trade. ${ }^{24}$ The Supreme Court has recognized both the paramount importance of combating the drug trade, ${ }^{25}$ and the tremendous obstacles

pickup outside home); California v. Ciraolo, 476 U.S. 207 (1986) (naked-eye observation of home from airplane); Dow Chem. Co. v. United States, 476 U.S. 227 (1986) (aerial observation of industrial plant with precision mapping camera); United States v. Karo, 468 U.S. 705 (1984) (monitoring a tracking device in a home and locker); United States v. Knotts, 460 U.S. 276 (1983) (monitoring a tracking device in a car); United States v. Place, 462 U.S. 696 (1983) (dog sniff of airport luggage); Smith v. Maryland, 442 U.S. 735 (1979) (use of "pen register" to monitor telephone records); Tyler v. Berodt, 877 F.2d 705 (8th Cir. 1989) (monitoring of cordlcss phone conversations); United States v. Taborda, 635 F.2d 131 (2d Cir. 1980) (use of long-range telescope); State v. Louis, 672 P.2d 708 (Or. 1983) (telephoto photography of home's interior); see also Brian J. Serr, Great Expectations of Privacy: A New Model for Fourth Amendment Protection, 73 Minn. L. Rev. 583, 585-86 (1989) (arguing that the Court's relaxed attitude toward law enforcement search and seizures permits greater threats of privacy invasion by the government).

21. See Serr, supra note 20 , at 586 .

22. E.g., Tyler, 887 F.2d at 705 .

23. Serr, supra note 20 , at 586 .

24. During the period from 1980 to 1989 , which roughly corresponds to the period between the 1979 decision of Smith $v$. Maryland and the 1939 decision of Florida $v$. Riley, the number of drug busts more than doubled from 377,175 to 852,105. Doug Bandow, War on Drugs or War on America?, 3 StAN. L. \& POL'y Rev. 242, 243 (1991). Drug arrests nationwide grew from 162,177 in 1968, about the time Katz was decided, to 1.15 million in 1989. Id. Federal anti-drug expenditures grew 300\% between 1980 and 1988, and totaled nearly $\$ 10$ billion in 1990. Id.

Justice Blackmun has commented that the "special need for flexibility in uncovering illicit drug couriers is hardly debatable." Florida v. Royer, 460 U.S. 491, 519 (1983) (Blackmun, J., dissenting). In contrast, Justice Marshall has decried the emergence of a "drug exception" to the Fourth Amendment. Skinner v. Railway Labor Executives' Ass'n, 489 U.S. 602, 641 (1989) (Marshall, J., dissenting). In any event, drugs may be only a convenient tool for the Court to pursue its broader objective of providing the police with wide latitude to control crime. "[T] the privacy concept, which originally was designed to expand the scope of fourth amendment protection, [has instead been used] to draw unrealistic distinctions in favor of law enforcement." Gerald G. Ashdown, The Fourth Amendment and the "Legitimate Expectation of Privacy," 34 VAND. L. REv. 1289, 1315 (1981). As Justice Douglas said in his lone dissent in Terry v. Ohio, "[t]here have been powerful hydraulic pressures throughout our history that bear heavily on the Court to water down constitutional guarantees and give the police the upper hand." 392 U.S. 1, 39 (1968) (Douglas, J., dissenting).

25. United States v. Mendenhall, 446 U.S. 544, 561 (1980) (opinion of Powell, J.) ("The public has a compelling interest in detecting those who would traffic in deadly drugs for personal profit"). 
that police face in confronting highly organized and hugely profitable drug operations. ${ }^{26}$ The fight against crime, and particularly the war on drugs, has led to intensified research into technologies intended to give law enforcement officers more powerful tools to detect criminal activity. Moreover, decreased defense spending has encouraged the conversion of military technologies for civilian law enforcement use. ${ }^{27}$ As the fight against crime has become more hi-tech, the courts have struggled to articulate a satisfying method for evaluating these technologies under the Fourth Amendment.

Despite the legitimacy of these concerns, the Katz test and its application have generated abundant criticism. ${ }^{28}$ Some commentators, for example, have exposed the ephemeral protection of Katz's "subjective" prong, pointing out that the government could neutralize citizens' subjective privacy expectations merely by broadcasting a regular public announcement that individuals would no longer have any privacy. ${ }^{29}$ Others have suggested that the subjective prong creates an impossible task: for people to manifest the expectation of privacy Katz demands, they have to take Draconian measures to insulate themselves from every

26. Id. at $561-62$.

27. E.g., Peter Fimrite, Cold War Gadgets Touted as Crimefighting Tools, S.F. ChroN., Oct. 25, 1994, at A13.

28. Given the large amount of legal commentary in the Fourth Amendment area, it is possible to include only a small sampling of the literature. Articles that have had particular influence on this author include Ashdown, supra note 24; John M.A. DiPippa, Is the Fourth Amendment Obsolete? Restating the Fourth Amendment In Functional Terms, 22 Gonz. L. Rev. 483 (1988); Paul Finkelman, The Second Casualty of War: Civil Liberties and the War on Drugs, 66 S. CAL. L. REv. 1389 (1993); Lewis R. Katz, In Search of a Fourth Amendment for the Twenty-first Century, 65 IND. L.J. 549 (1990); John B. Mitchell, What Went Wrong with the Warren Court's Conception of the Fourth Amendment?, 27 NEw ENG. L. Rev. 35 (1992); Serr, supra note 20; Silas J. Wasserstrom, The Incredible Shrinking Fourth Amendment, 21 AM. CRIM. L. REv. 257 (1984); Richard G. Wilkins, Defining the "Reasonable Expectation of Privacy": An Emerging Tripartite Analysis, 40 VAND. L. REv. 1077 (1987); Michael Campbell, Comment, Defining a Fourth Amendment Search: A Critique of the Supreme Court's Post-Katz Jurisprudence, 61 WASH. L. REv. 191 (1986).

29. Anthony G. Amsterdam, Perspectives on the Fourth Amendment, 58 MinN. L. REv. 349, 384 (1979) ("[T]he government could diminish each person's subjcctive expectation of privacy merely by announcing half-hourly on television ... that we were all forthwith being placed under comprehensive electronic surveillance."). Several years after Amsterdam's article, the Supreme Court recognized the legitimacy of this criticism:

Situations can be imagined, of course, in which Katz' two-pronged inquiry would provide an inadequate index of Fourth Amendment protection. For example, if the Government were suddenly to announce on nationwide television that all homes henceforth would be subject to warrantless entry, individuals thereafter might not in fact entertain any actual expectation of privacy regarding their homes, papers, and effects.... In such circumstances, where an individual's subjective expectations had been "conditioned" by influences alien to well-recognized Fourth Amendment freedoms, those subjective expectations obviously could play no meaningful role in ascertaining what the scope of Fourth Amendment protection was. In determining whether a "legitimate expectation of privacy" existed in such cases, a normative inquiry would be proper.

Smith v. Maryland, 442 U.S. 735,740 n.5 (1974). To the frustration of commentators, the Court has never explained what form such a "normative inquiry" might take. 
conceivable intrusion by the government, likely or not..$^{30}$ Even the Court itself has exhibited deep ambiguity regarding how far to "push the envelope" with respect to the subjective prong of the Katz test. ${ }^{31}$

The Court's treatment of Katz's objective prong also has come under widespread attack. Commentators have argued that the Katz test, which was designed to preserve the common sense privacy interests of citizens, ${ }^{32}$ has been perverted by the Court's insistence that an individual cannot reasonably retain an expectation of privacy in activities that have been "expose[d] to the public, ${ }^{, 33}$ even to a minuscule degree. ${ }^{34}$ Moreover, studies have shown that the Court's view of which government intrusions citizens would consider "reasonable" does not always comport with reality. ${ }^{35}$

The above exemplifies only a sampling of the sustained, widespread criticism that has been leveled at the Court for its systematic narrowing of Katz since the 1979 decision of Smith v. Maryland ${ }^{36}$ where the Court held that the government need not obtain a warrant to monitor and record the phone numbers dialed from one's liome. ${ }^{37}$ Most recently, the debate over thermal imagers has re-energized the anti-Katz

30. Dow Chem. Co.v. United States illustrates this conundrum: the Court held that Dow failed the Katz test because it failed to make any effort to protect against aerial surveillance, even though the company had taken admittedly elaborate precautions to protect against ground-level viewing. 476 U.S. 227, 229, 237 (1986). See supra notes 130-135 and accompanying text for a fuller discussion of the Dow opinion.

31. For example, in hair-splitting contrast to the Dow opinion, see supra note 30 , the Court recognized in another case (the companion case to Dow) that a defendant's attempts to protect against ground-level observation could, in the appropriate case, be sufficient to reflect the necessary subjective expectation of privacy against aerial surveillance. See California v. Ciraolo, 476 U.S. 207, 211-12 (1986).

32. See Katz v. United States, 389 U.S. 347, $351-52$ (1967) ("[W] hat [an individual] seeks to preserve as private, even in an area accessible to the public, may be constitutionally protected.").

33. See id. at 351 ("What a person knowingly exposes to the publie, even in his own home or office, is not a subject of Fourth Amcndment protection.").

34. See Ashdown, supra note 24 , at 1315 "Extrapolating a complete forfeiture of privacy from a minor voluntary disclosure for a specific, limited purpose is indicative of a complete lack of appreciation for the notion of relativity."); Serr, supra note 20, at 598 ("[T] he Court has severed [the 'knowingly exposes to the public'] language from its context and used it as a talisman, ruling that any objects, statements, or activities exposed to the public-even if exposed only to a very limited degree-do not deserve fourth amendment protection.").

35. Christopher Slobogin \& Joseph Schumacher', Reasonable Expectations of Privacy and Autonomy in Fourth Amendment Cases: An Empirical Look At "Understandings Recognized and Permitted By Society," 42 DUKE L.J. 727, 733-39.759-61 (1993); see also Ashdown, supra note 24, at 1315 ("[T]elephone patrons undoubtedly would be shocked to learn that records of their calls either were available for third parties or were being distributed outside the telephone system. Beyond the necessary internal business practices of the telephone company, people expect their use of the telephone to be absolutely private, and it is reasonable for them to believe that the numbers dialed from private telephones are as free from uncontrolled government seizure as are their telephone conversations.").

36. 442 U.S. 735 (1979).

37. Id. at 745-46. See infra notes 88-99 and accompanying text for a fuller discussion of the Smith decision. 
camp and its calls for a wholesale replacement of the Katz test. ${ }^{38}$ However, while these commentators have done an exceptional job of elaborating the doctrinal limitations of Katz as currently applied, they have failed to provide practical guidance to a Supreme Court that has consistently rejected calls to revamp Katz's expectation of privacy test.

This Comment recognizes that, despite its many shortcomings, modern Fourth Amendment search analysis is firmly rooted in the Katz tradition. The Supreme Court has made it abundantly clear that it does not wish to jettison Katz's two-step expectation of privacy test. The Court has decided a number of major search cases during the past twenty years, and although its analysis has been strained at times, it has consistently managed to apply $\mathrm{Katz}$ to its apparent satisfaction. Moreover, since at least five current members of the Court have been members of the majority in recent decisions applying $K a t z$ to limit Fourth Amendment protections, it is unlikely the Court will replace Katz any time soon. ${ }^{39}$

Nevertheless, newly emerging technologies are poised to begin confounding the Court's privacy framework, and the thermal imaging cases highlight many of the doctrinal problems the Court will soon be forced to consider. To be sure, many courts have appeared quite comfortable evaluating the constitutionality of thermal imagers under the Katz test. The majority of these courts have held that use of these devices does not constitute a Fourth Amendment search. ${ }^{40}$ That result, while troubling to this author, is not particularly surprising; FLIRs are less intrusive than other activities the Court has refused to recognize as

38. Hale, supra note 6 , at $846-47$ (positing a "plain meaning" approach to the Fourth Amendment, whereby a "search" occurs whenever technology allows police to "look into a structure and discover something that is going on inside"); Moore, supra note 6 , at $840-41$ (arguing that the Court has improperly extrapolated citizens' tolerance of privacy intrusions by private actors into a broader tolerance of intrusions by government agents); Polatsek, supra note 6, at 476-79 (arguing that technological advances have made clear that the Katz standard is unworkable, and proposing that Katz be replaced by a functional test that "focuses on the character of the information revealed" and "examines whether one's private affairs have been intruded upon"). But see Steele, supra note 6, at 30-39 (adopting the position, without criticizing Supreme Court case law, that those cases should be interpreted to require a warrant for the use of FLIRs).

39. For example, in Florida v. Riley, Chief Justice Rehnquist and Justices Scalia, Kennedy, and O'Connor, together with now-retired Justice White, held that the naked-eye observation of the interior of a greenhouse from a helicopter at 400 feet does not constitute a Fourth Amendment search. Riley. 488 U.S. 445 (1989). Justice Stevens' views are more uncertain, as he dissented in Riley but joined the majority in California v. Ciraolo, 476 U.S. 207 (1986), holding that the aerial observation of a fenced-in backyard from a helicopter at 1,000 feet does not constitute a search. See infra notes 121-129 and accompanying text for further discussion of Ciraolo. Justices Brennan and Marshall, who dissented in these cases as well as in Dow Chem. Co. v. United States, Smith v. Maryland, and California v. Greenwood, see infra notes 88-149 and accompanying text, are no longer on the Court. Justices Souter, Thomas, Breyer, and Ginsburg were not yet on the Court when the above cases were decided.

40. See supra note 3 . 
searches. For example, the vast majority of homeowners, if given the choice between helicopter surveillance of their backyard (which does not require a warrant) ${ }^{41}$ and the use of a FLIR on their property, would likely choose thermal detection of their home.

While that result is arguably tolerable to most citizens, the broader implications of the thermal imaging cases are far more disturbing. If the lower courts have been correct in the way in which they have applied Katz and its successor cases to thermal imagers, then they have thrown the door wide open to warrantless invasions that far transcend thermal inspection of private homes. This Comment argues, however, that the root of the problem is not Katz itself, nor even necessarily the line of Supreme Court cases following Katz that have substantially weakened Fourth Amendment protections. The principal error committed by the courts that have held FLIR use not to constitute a search is that they have failed to apply $\mathrm{Katz}$ in a manner consistent with long-recognized Fourth Amendment values which, contrary to the opinion of many commentators, are still alive, kicking, and present in most of the Court's post-Katz decisions.

Given that nearly all of the Supreme Court's post-Katz cases have yielded results that appear strongly to favor law enforcement, it is not surprising that most lower courts have erred in concluding that thermal imagers do not constitute a search. Without proper guidance, other courts will likely commit similar errors in the future as they wrestle with the constitutionality of new law enforcement technologies. This Comment seeks to simplify, clarify, and systematize this evaluative process for the lower courts. The objective is to uncover criteria, found throughout the Court's post-Katz jurisprudence, that can be used to evaluate whether and to what degree emerging law enforcement technologies, including FLIRs, comport with the values that underlie the Fourth Amendment.

The four criteria, or "guideposts," presented in this Comment are essential tools for courts to use when evaluating future law enforcement devices that will inevitably test the outer limits of public acceptability and constitutionality. These criteria include the area subject to surveillance by the particular technology or device, the nature of the information the technology can disclose to the police, the degree of public awareness regarding the technology, and the degree of intrusion into our private lives that the device makes possible. A discussion of these criteria in the thermal imaging context will make clear that, for a variety of reasons that members of the current Court have themselves espoused, the use of a sophisticated technology such as thermal imagers to detect illegal activity in the home constitutes a Fourth Amendment search.

41. Riley, 488 U.S. at 445. 
Part I begins by giving a brief description of the technology and function of thermal imaging devices and their current uses in law enforcement. The discussion will be used to explain why so many courts have refused to hold the use of these devices to constitute a search: although FLIRs are more invasive than other technologies the Court has considered, they do not typically reveal intimate detail to such an extent that they are obviously constitutionally suspect. Part II discusses the Katz framework and its evolution and application since 1967. Part III examines the thermal imaging case law and explores how the courts have applied Katz and its progeny to FLIR technology. Part IV discusses the benefits and drawbacks of using technology to fight crime, exploring in particular the unique way in which technology augments our senses of perception as well as how technology shapes our privacy expectations and Fourth Amendment values. Finally, Part V enumerates the four "guideposts" for the Court to consider when it finally confronts the constitutionality of thermal imaging devices and other advanced search technologies. This discussion will reveal that, while the Court's post-Katz jurisprudence provides a somewhat shaky framework for evaluating new technologies in accordance with fundamental Fourth Amendment values, a proper application of these criteria can enable the Court to accomplish exactly that task.

I

\section{A Hot Topic: Thermal Imagers in Practice}

Thermal imaging devices create a picture based on heat emissions much as a camera creates a picture based on light. When directed toward an object, FLIRs retrieve thermal information from the surface of that object with extraordinary sensitivity: as little as a 0.2 degree centigrade differential can be detected. ${ }^{42}$ This information is converted into electrical signals and then processed into a two-dimensional image. ${ }^{43}$ The resulting image appears in shades of gray, depending on the amount of heat being emitted from the object and the object's ability to transmit that heat. ${ }^{44}$ The image, which looks like a black-and-white TV picture, ${ }^{45}$ can be displayed on a screen or stored on videotape. The devices are most commonly either hand-held or mounted underneath a helicopter. $^{46}$

42. Steele, supra note 6 , at 24.

43. Stephen M. Hardy, Night Eyes Open Wider: Night Vision Equipment, J. Electronic Def., Aug. 1993, at 35, available in LEXIS, Nexis Library, Archnews File.

44. Steele, supra note 6 , at 24 .

45. Hardy, supra note 43.

46. Steele, supra note 6 , at 24 . 
Although the use of thermal imagers in drug enforcement is relatively new, the technology itself is not. The military has long used FLIRs in combat situations for such purposes as weapons targeting, and continues to employ the devices for surveillance, reconnaissance, and navigational assistance. ${ }^{47}$ Unlike typical night-vision goggles, which amplify visible light, FLIRs can function in total darkness, haze, smoke, and fog, making them well-suited for battlefield application. ${ }^{48}$ Most recently, successful use of FLIRs by the military in the Persian Gulf War has led to increased FLIR use in a wide variety of domestic industrial applications. ${ }^{49}$

The use of thermal imagers in law enforcement settings is similarly varied. FLIRs are used to aid search-and-rescue operations and to detect fleeing suspects, missing children, and escaped convicts. ${ }^{50}$ They help the Danish navy detect illicit fishing activities ${ }^{51}$ and the U.S. Border Patrol catch illegal immigrants. ${ }^{52}$ The National Guard recently even used a thermal imager to locate and capture a two-year-old Bengal tiger that had escaped from the circus. ${ }^{53}$

The most common use by civilian law enforcement authorities, however, is for the detection of indoor marijuana "grows." Marijuana cultivation is a booming industry, both for drug dealers and for individuals who, eager to avoid the risks and high costs of buying from dealers, grow smaller quantities of marijuana for personal use. ${ }^{54}$ Growers are increasingly moving their crops indoors, using artificial light and

47. Janice Fioravante, Night Sight, InvestoR's Bus. DAILY, Feb. 26, 1995, at A6.

48. Barry Mitzman, The Northwest Investor: Infrared Visionary FLIR Looks Fonward to Busy Peacetime Sales, News TriB., Nov. 13, 1994, at G5, available in WESTLAW, Allnews Database.

49. Id. For example, thermal imagers can be used to detect wear and defects in machinery, in power transmission lines, and in building structures, since worn-out ball bearings, leaky insulation, and cracking concrete all emit heat. Id. They are used in steel mills and pulp and paper plants to detect production-line temperatures from a safe distance. Richard Colby, Thermal Imaging Heats Up. ThE OREgonian, Jan. 14, 1994, at C1. FLIRs are also used for environmental protection activities such as forest fire detection, oil spill detection, and wildlife management. Fioravante, supra note 47, at $\mathrm{A6}$.

50. See. e.g., Colby, supra note 49 (relating how Los Angeles police used a thermal imager to catch a murder suspect at night: an officer circling overhead in a helicopter used a FLIR to detect the suspect's body heat, and then related the suspect's location by radio to an officer on the ground standing only a few feet away from the suspect); Ralph Ellis, Heat-Seeking Helicopter Device to Aid Clayton Police Searches, ATLANTA J., Dec. 29, 1994, at J1.

51. Colby, supra note 49 , at C5.

52. Frontline: Go Back to Mexico (PBS Television Broadcast, June 7, 1994), available in WESTLAW, Allnews Database.

53. National Guard Helps Capture Circus Tiger, ThE FORT WORTH STAR-TeLEGRAM, Feb. 11, 1995 , at 25.

54. Daniel Machalaba, Growing Pot at Home Often Turns Out to Be a Real Bust, WALL ST. J, Apr. 21, 1993, at A1. It is estimated that one to three million Americans grow marijuana, of whom approximately 100,000 to 200,000 are commercial growers. Eric Schlosser, Reefer Madness, THE Atlantic, Aug. 1994, at 62. 
hydroponics to avoid theft, reduce the risk of detection, control the growing process, and cultivate multiple harvests each year. ${ }^{55}$

The principal thermal imaging cases, discussed in Part III, concern commercial growers who cultivate hundreds, even thousands, of plants in their basements, garages, and outbuildings. These grows are sophisticated hydroponic operations, involving powerful 1000-watt halide lamps and complex cooling, ventilation, and irrigation systems. ${ }^{56}$ The halide lamps, which burn eighteen hours a day during certain phases of the growing cycle,$^{57}$ can generate heat of 150 degrees or more..$^{58} \mathrm{Be}$ cause the optimal growing temperature for marijuana is approximately seventy degrees, the excess heat generated by these bulbs must be vented or internally cooled. ${ }^{59}$ A marijuana grow may have its own generator to power the heat lamps in order to avoid alerting the police, who recognize that excessively high power consumption is a likely sign of marijuana cultivation..$^{60}$

Before using a thermal imaging device on a building, police typically will have some reason to suspect that a marijuana grow is located inside. Often, an informant will tip off the police, ${ }^{61}$ who will then attempt to obtain a search warrant for the building. In order to satisfy the probable cause requirement necessary for a warrant, the police may take one or more of the following steps. They may conduct visual surveillance of the property, perhaps taking note of blacked-out windows, external exhaust fans, and other indications of indoor marijuana cultivation. They may subpoena electrical utility records to determine whether the property is drawing an unusually large amount of power. ${ }^{62}$ Finally, and most frequently, they may use a thermal imager to conduct a warrantless thermal inspection of the property. An officer trained in FLIR use will either enter the property (taking care to remain in the "open fields"63) or will fly a helicopter over the property. Detection of

55. Schlosser, supra note 54 , at 60 .

56. Id. at $56,62-63$.

57. Id. at 63 .

58. United States v. Pinson, 24 F.3d 1056, 1057 (8th Cir.), cert. denied, 115 S. Ct. 664 (1994).

59. Id. at 1057-58.

60. See, e.g., id. at 1057 (search warrant affidavit contained, in addition to thermal imaging data, information concerning unusually high electrical usage at defendant's home, which was indicative of indoor marijuana cultivation).

61. See, e.g., United States v. Penny-Feeney, 773 F. Supp. 220, 221-23 (D. Haw. 1991) (police began to investigate suspect after receiving informants' tips that defendant was growing marijuana at residence), aff'd on other grounds sub nom. United States v. Feeney, 984 F.2d 1053 (9th Cir. 1993).

62. See, e.g., United States v. 1shmael, 48 F.3d 850, 852 (5th Cir.), cert. denied, 116 S. Ct. 74 (1995).

63. Under the "open fields" doctrine, "an individual may not legitimately demand privacy for activities conducted out of doors in fields, except in the area immediately surrounding the home" (the "curtilage"). Oliver v. United States, 466 U.S. 170, 178 (1984). Only the curtilage, and not the neighboring open fields, merits the Fourth Amendment protections that attach to the home. Id. at 180 . 
unusually high levels of heat from within a building will be interpreted as a strong sign of a marijuana grow inside.

This information, combined with other information the officer has discovered, is usually enough to meet the probable cause requirement for a search warrant. At issue in the thermal imaging case law is whether use of a FLIR is itself a "search" that requires a warrant. This question has been evaluated by the courts under the framework provided by Katz v. United States ${ }^{64}$ and its progeny.

II

KATZ \& CO.: A FOUNDATION UNDER ATTACK

\section{A. The Revolution of Katz}

Prior to Katz, the Supreme Court viewed the Fourth Amendment as a tool for regulating searches and seizures of tangible property only. For instance, in Olmstead $v$. United States, ${ }^{65}$ the Court held that use of a government-sponsored wiretap did not constitute a Fourth Amendment search. Relying on the text of the Fourth Amendment, which "itself shows that the search is to be of material things - the person, the house, his papers, or his effects," lice inserted the wiretaps without trespassing on the defendants' property. ${ }^{67}$ Because police obtained the evidence only through the agents' sense of hearing, without physically invading the house, offices, or other protected areas, no search or seizure occurred. ${ }^{68}$

This narrow textual interpretation of the Fourth Amendinent survived for almost forty years. During that period, the government relied on concepts of "constitutionally protected areas" and common-law notions of trespass to conduct a wide variety of activities without Fourth Amendment safeguards. ${ }^{69}$ Only if the government somehow intruded on the physical sanctity of the home would the courts find a Fourth

Therefore, under the Fourth Amendment, the police are free to trespass on one's property without a search warrant, so long as they do not intrude into areas immediately surrounding the home. In most thermal imaging cases, officers physically enter a person's private property at night and approach a home or outbuilding to take thermal readings from a close distance that is outside the curtilage.

64. 389 U.S. 347 (1967).

65. 277 U.S. 438 (1928).

66. Id. at 464 .

67. Id. at 457 .

68. Id. at 464 .

69. See, e.g., Goldman v. United States, 316 U.S. 129 (1942) (Fourth Amendment not implicated when government agents applied sound amplification devices to wall of room adjoining defendant's office to detect private conversations), overruled in part by Katz v. United States, 389 U.S. 347 (1967). 
Amendment search. ${ }^{70}$ Otherwise, as long as no physical search was conducted, the police were free to intrude on citizens' privacy interests.

The facts of Katz, however, forced the Court to reexamine these assumptions. The FBI suspected that Charles Katz was illegally transmitting gambling information by telephone to individuals in several states. $^{71}$ FBI agents attached a wiretap to the outside wall of the public telephone booth from which Katz was making his calls and recorded his conversations. ${ }^{72}$ The district court and court of appeals, in accordance with Olmstead, ruled that the recordings did not violate the Fourth Amendment because neither the police nor the wiretap physically intruded into the phone booth. ${ }^{73}$

The Supreme Court reversed. The Court recognized that, contrary to the spirit of the Fourth Amendment, modern technology afforded the government significant opportunities for invading personal privacy without intruding into physical space. Stating that "the Fourth Amendment protects people, not places, "74 the Court rejected the idea that only searches and seizures of tangible property were protected, and applied the Fourth Amendment to invasions of personal privacy even absent a physical trespass. Because the Court found Katz's reliance on the closed telephone booth for privacy to be justifiable, ${ }^{75}$ his conversation was entitled to Fourth Amendment protection. The police could only monitor that conversation pursuant to a warrant based on a showing of probable cause. ${ }^{76}$

Although the majority opinion provided the true break with the past, it is Justice Harlan's concurring opinion that established the seminal two-pronged test to determine whether Fourth Amendment protections attach. First, the individual inust manifest an actual, subjective expectation that the activity will remain private. ${ }^{77}$ Second, this expectation must "be one that society is prepared to recognize as 'reasonable." "78 Because Katz entered the phone booth and closed the door behind him with the subjective belief that his conversation would not be intercepted, and because he was objectively entitled to that belief, he satisfied both prongs of Justice Harlan's privacy test. ${ }^{79}$ The FBI's

70. See, e.g., Silverman v. United States, 365 U.S. 505 (1961) (evidence excluded because it was obtained by use of a microphone inserted under the baseboard of a wall of defendant's house).

71. Katz, 389 U.S. at 348.

72. Id.

73. See id. at $348-49$.

74. Id. at 351 .

75. Id. at 353.

76. Id. at 358-59.

77. Id. at 361 (Harlan, J., concurring).

78. Id.

79. Id. 
warrantless recording of his conversation therefore violated the Fourth Amendment. ${ }^{80}$

\section{B. The Promise of Katz Denied}

\section{The First Blow: Smith v. Maryland}

Since Katz, the Court has repeatedly used Justice Harlan's two-part "expectation of privacy" test to determine whether various privacy interests merit Fourth Amendment protection. ${ }^{81}$ However, this show of loyalty to $\mathrm{Katz}$ has proven specious, for subsequent cases have substantially undermined the promise of $\mathrm{Katz}$ while simultaneously purporting to uphold its substantial protections. Today, most Americans would be appalled at the range of government intrusions that are permitted without a search warrant. The Supreme Court has held that without a warrant, the police may hover above your house in a helicopter to look for marijuana through windows and skylights, ${ }^{82}$ rummage through your garbage to learn about your private life, ${ }^{83}$ track your vehicle using devices placed in objects you may carry in your car, ${ }^{84}$ obtain a list of numbers you call from home, ${ }^{85}$ and trespass on your property to examine the premises, so long as they do not come too close to your house. ${ }^{86}$ These search techniques are also allowed with regard to commercial establishments. The police may, for example, use a plane to spy on a heavily guarded industrial plant, and even use a precision aerial mapping camera to photograph the property. ${ }^{87}$

This series of decisions was launched in 1979 with Smith v. Maryland ${ }^{88}$ where the Supreme Court held that the police's warrantless use of a "pen register," a device installed at the telephone company and used to record the phone numbers dialed from one's home, did not violate the Fourth Amendment. Michael Smith was suspected of robbing a woman and subsequently making threatening and obscene phone calls to her. At police request, the telephone company attached a pen register at their central office to Smith's phone line. After the register revealed that Smith was calling the robbery victim's home, the police utilized this and other information to obtain a warrant to search Smith's residence.

80. Id.

81. See, e.g., Florida v. Riley, 488 U.S. 445,449 (1989); California v. Greenwood, 486 U.S. 35 , 39 (1988); California v. Ciraolo, 476 U.S. 207, 211 (1986); Dow Chem. Co. v. United States, 476 U.S. 227, 236 (1986); Oliver v. United States, 466 U.S. 170, 177 (1984); United States v. Knotts, 460 U.S. 276, 280-81 (1983); Smith v. Maryland, 442 U.S. 735, 740 (1979).

82. See Ciraolo, 476 U.S. at 207.

83. Greenwood, 486 U.S. at 35.

84. United States v. Karo, 468 U.S. 705 (1984).

85. Smith, 442 U.S. at 735.

86. United States v. Dunn, 480 U.S. 294 (1987).

87. Dow Chem. Co. v. United States, 476 U.S. 227 (1986).

88. 442 U.S. 735 (1979). 
Smith was arrested, the pen register record was admitted into evidence at trial, and he was subsequently convicted of robbery. ${ }^{89}$

In a 5-3 decision, the Supreme Court used the Katz expectation of privacy test to uphold the warrantless use of the pen register. First, the Court rejected the notion that Smith had manifested a subjective expectation of privacy in the phone numbers he dialed. ${ }^{90}$ Telephone subscribers "know" the numbers they call will not remain secret: they see a list of their calls on their monthly bill, and they are aware the telephone company can help police track down obscene callers. ${ }^{91}$ Thus, the Court found it was "too much to believe that telephone subscribers, under these circumstances, harbor any general expectation that the numbers they dial will remain secret."192

Second, even if Smith did harbor such an expectation, the Court held that it was not one society is prepared to recognize as reasonable. ${ }^{93}$ A person has no legitimate expectation of privacy in information he voluntarily turns over to third parties. ${ }^{94}$ Here, by "exposing" the numbers he dialed to the telephone company, Smith assumed the risk that this information ultimately would be turned over to the police. ${ }^{95}$

The dissenters challenged this application of Katz on two key grounds. First, the mere fact that telephone company equipment transmits the call does not mean that a caller yields her expectation of privacy in the phone numbers dialed; telephone company equipment could also record the conversation that is "exposed" to the company, but Katz clearly forbids that. ${ }^{96}$ Second, even if one assumes that individuals typically are aware that the phone company monitors the numbers its subscribers dial, "it does not follow that they expect this information to be made available to the public in general or the government in particular." 97 The dissent's reasoning is simple common sense: when a person discloses limited information to a phone company, a credit card issuer, or a bank, she does not expect that information to be distributed freely to the police, her employer, or her political opponents. Rather, she simply discloses the information for a "limited business purpose" with the assumption that the information would not be

\footnotetext{
89. Id. at 737-38.

90. Id. at 736 .

91. Id. at $742-43$.

92. Id. at 743 .

93. Id.

94. Id. at 743-44.

95. Id. at 744.

96. Id. at $746-47$ (Stewart, J., dissenting).

97. Id. at 749 (Marshall, J., dissenting).
} 
released for other purposes. ${ }^{98}$ One commentator has summarized the decision as follows:

The theory that emerged in Smith provides that if a person exposes any activity, statement, or object-however intimate-to any other member of the public, in any degree, the person assumes the risk that the third party will reveal to the government anything so exposed. No fourth amendment protection therefore exists against police efforts specifically designed to detect such intimate, albeit "exposed" information, even when the police take a much closer look than the limited "public exposure" allows. ${ }^{99}$

\section{More Restrictions: A Fourth Amendment in Big Brother's Clothing}

Since 1979, a series of decisions have continued to erode Fourth Amendment protections, constructing new additions to the house that Smith built. In United States v. Knotts, ${ }^{100}$ the Supreme Court unanimously approved the warrantless monitoring of a beeper to track the movements of a suspected drug trio. Police suspected one defendant, Armstrong, of purchasing chemicals to manufacture drugs. ${ }^{101}$ With the consent of the chemical company, police officers placed a tracking device in a container of chloroform that Armstrong was about to purchase, and then used the beeper to follow Armstrong while he transported the chemicals in his car to another co-defendant, Petschen. ${ }^{102}$ Still using the beeper, the officers then followed Petschen's car to defendant Knotts' secluded cabin. ${ }^{103}$ Relying on the location of the chemicals derived through the use of the beeper, and additional information garnered from visual surveillance of the cabin, the police were able to gather enough information to obtain a search warrant. ${ }^{104}$ Finding drug producing chemicals and equipment in the cabm, the police arrested Knotts. ${ }^{105}$

The Court applied Katz's two-part expectation of privacy test and held that the monitoring of beeper signals did not invade Knotts' reasonable expectation of privacy. ${ }^{106}$ Co-defendant Petschen was driving his car on public streets, in the plam view of those around him, and therefore "voluntarily conveyed to anyone who wanted to look" his

98. See id. (Marshall, J., dissenting) (citing California Bankers Ass'n v. Shultz, 416 U.S. 21, 9596 (1974) (Marshall, J., dissenting)).

99. Serr, supra note 20 , at 600 .

100. 460 U.S. $276(1983)$.

101. Id. at 278 .

102. Id.

103. Id.

104. Id. at 279.

105. Id.

106. Id. at 285. 
route, itinerary, and final destination..$^{107}$ In addition, the police were free to "augment[] the sensory faculties bestowed upon them at birth with such enhancement as science and technology afforded them in this case." 108 .

Although it seems unusual to argue that driving on public streets equates to an awareness that the police may place a tracking beeper in your car, the Knotts decision was, in several respects, an easier decision than Smith v. Maryland or many of the decisions that would follow. First, the Court declined to rule on the warrantless installation of the beeper, and only held the monitoring of the device could be conducted without a warrant. ${ }^{109}$ Second, the Court consistently has held that the privacy interests associated with one's automobile are considerably weaker than the privacy interests associated with one's residence. ${ }^{110}$ Since a car is in plain view of the public at all times, police monitoring of a car is less disturbing than the telephone company using information available only to the company to record phone numbers dialed from home, later turned over to others. Nor did the police use the beeper to track the movements of the container once it was inside Knotts' residence, where it would have been impossible to view from a public vantage point outside his home. ${ }^{111}$

One year later, the Supreme Court decided United States v. Karo, ${ }^{112}$ another beeper case that has the distinction of being the only major post-Katz search case to invalidate the use of law enforcement technology. In Karo, an informant (an ether vendor) notified the government that the defendant had ordered ether to extract cocaine from imported clothing. ${ }^{113}$ The government received permission from the informant to install a beeper in one of the cans of ether the defendant planned to buy. When the defendant picked up the can, the police tracked the ether to the defendant's house, and later to a co-defendant's residence. ${ }^{14}$

The Court held the monitoring of the beeper inside the defendant's home to be a search in violation of the Fourth Amendment. The beeper "reveal[ed] a critical fact about the interior of the premises that the Government [was] extreinely interested in knowing and that it could not have otherwise obtained without a warrant." 115 Unlike Knotts, where the

107. Id. at 281-82.

108. Id. at 282.

109. Id. at 279 n.1. Justices Stevens, Brennan, and Marshall did indicate that their position might be different if the installation of the beeper were at issue. See id. at 286 (Brennan, J., concurring); see id. at 288 (Stevens, J., concurring).

110. See id. at 281; Rakas v. Illinois, 439 U.S. 128, 153-54 \& n.2 (1978) (Powell, J., concurring).

111. Knotts, 460 U.S. at 285.

112. 468 U.S. 705 (1984).

113. Id. at 708 .

114. Id.

115. Id. at 715 . 
government stopped monitoring the beeper once it entered the defendant's home, here the government continued to monitor the location of the ether for a significant period of time in a constitutionally protected area." The Court held that "[i]ndiscriminate monitoring of property that has been withdrawn from public view would present far too serious a threat to privacy interests in the home to escape entirely some sort of Fourth Amendment oversight." 117

Karo is the only post-Katz decision to turn the clock back, ever so slightly, toward increased Fourth Amendment protection. Because it dealt with technology providing information about the interior of a home-the most constitutionally sacrosanct area ${ }^{118}$ - it seems particularly relevant to the thermal imaging question, as FLIRs detect thermal information emanating from within a home. However, two subsequent technology-related cases backed away from the minimal protections Karo purported to offer. These opinions, published together in May 1986, were California v. Ciraolo ${ }^{119}$ and Dow Chemical Co. v. United States. ${ }^{120}$

In Ciraolo, the Santa Clara, California police received a tip that the defendant was growing marijuana in his backyard, ${ }^{121}$ but were unable to view the area because Ciraolo had erected two high fences around the yard. ${ }^{122}$ Two enterprising officers flew a private plane over the defendant's house at an altitude of 1,000 feet, where they were able to identify a number of marijuana plants in the defendant's backyard. ${ }^{123}$ They subsequently obtained a search warrant based on this information. ${ }^{124}$

The Court held that the warrantless aerial search did not violate the Katz test. Although Ciraolo had exhibited a subjective expectation of privacy by building the fences, ${ }^{125}$ that expectation was only legitimate if "the government's intrusion [had] infringe[d] upon the personal and societal values protected by the Fourth Amendment."126 Even though the Court seemed to concede that the backyard was curtilage, ${ }^{127}$ and thus

116. Id.

117. Id. at 716 .

118. See Dow Chem. Co. v. United States, 476 U.S. 227, 237 n.4 (1986) (discussing how "privacy expectations are most heightened" in the home and areas immediately adjacent to the home).

119. 476 U.S. 207 (1986)

120. 476 U.S. 227 (1986).

121. Ciraolo, 476 U.S. at 209.

122. Id.

123. Id.

124. Id.

125. Id. at 211-14.

126. Id. at 212 (quoting Oliver v. United States, 466 U.S. 170, 181-83 (1984)).

127. Id. at 213. The term "curtilage" denotes the physical area immediately surrounding the home, "an area intimately linked to the home, both physically and psychologically, where privacy expectations are most heightened." Id. 
generally subject to Fourth Amendment protection, it held that Ciraolo was not protected because he had left his backyard visible from the air, thereby "knowingly expos[ing it] to the public." 128 Ciraolo had restricted the officers' ability to observe only from the ground, not from the air, and an officer is entitled to observe anything "from a public vantage point where he has a right to be."129

The astonishing conclusion, therefore, is that one has no legitimate expectation of privacy in anything that can be detected from a "public" vantage point, such as navigable airspace. Dow Chemical Co. v. United States, ${ }^{130}$ decided the same day, made clear that this was exactly what the Court meant. In Dow Chemical, the Environmental Protection Agency ("EPA") requested permission to inspect one of Dow's manufacturing plants, and Dow refused. Rather than seeking an administrative search warrant, the EPA employed a commercial photographer to take aerial photographs of the plant using a precision mapping camera. ${ }^{131}$ This was the only way for the EPA to gain information about the plant, which featured elaborate security barring ground-level views. ${ }^{132}$

The Supreme Court upheld the search. Although Dow had a reasonable and legitimate expectation of privacy within the interior of its covered buildings, the company had not made any effort to protect against aerial surveillance. ${ }^{133}$ Moreover, the Court felt the technology involved was not troubling:

Here, EPA was not employing some unique sensory device that, for example, could penetrate the walls of buildings and record conversations in Dow's plants, offices, or laboratories, but rather a conventional, albeit precise, commercial camera commonly used in mapmaking. ... It may well be, as the Government concedes, that surveillance of private property by using highly sophisticated surveillance equipment not generally available to the public, such as satellite technology, might be constitutionally proscribed absent a warrant. But the photographs here

128. Id. (quoting Katz v. United States, 389 U.S. 347, 351 (1967)). This same reasoning was applied in Smith v. Maryland to uphold the government's use of a pen register: because that defendant had "exposed" his phone records to the telephone company, he had forfeited all expectation of privacy in those records. See supra notes 88-95 and accompanying text.

129. Ciraolo, 476 U.S. at 213.

130. 476 U.S. 227 (1986).

131. Id. at 229.

132. Id.

133. Id. at 237. In actuality, Dow did investigate all low-level aircraft flights over the facility. Id. at 229. One must assume that such an investigation is not sufficient, in the Court's eyes, to evidence a subjective expectation of privacy against aerial intrusion. The Court ignored the fact that the cost of Dow covering 2,000 acres of exposed equipment would be prohibitive. $l d$. 
are not so revealing of intimate details as to raise constitutional concerns. ${ }^{134}$

Thus, Dow Chemical Company was simply out of luck. While the Court paid lip service to the fact that Dow could not be expected to erect a huge roof or cover over its entire 2,000-acre tract, ${ }^{135}$ apparently no lesser measure would have been sufficient to protect against unwelcome government intrusion. Moreover, the Court provided no indication as to the point at which technology-assisted surveillance becomes so intrusive that society refuses to recognize it as reasonable. That point has not been reached with pen registers, tracking devices, or aerial observation, even if camera-assisted. The Court's throwaway remark in Dow Chemical that the use of satellite technology might require a warrant provides no instruction as to where (if anywhere) the line demarcating searches from non-searches is to be drawn. If courts use the "general[] availab[ility] to the public"136 of the technology as the dispositive issue, then citizens will have great cause for concern as civilian technologies become cheaper, more advanced, and more widely used.

\section{Further Intrusions Allowed: What's All This Garbage?}

In 1988, the Supreme Court added another highly intrusive technique to the already lengthy list of activities the police could conduct without a warrant: the search of private garbage. Although garbage searches are distinctly not technological in character, most of the thermal imaging cases discussed in Part III have analogized a FLIR search to the search of garbage at issue in California $v$. Greenwood. ${ }^{137}$

In Greenwood, the police received a tip that the defendant was using his home as the center of a drug trafficking operation. After police surveillance failed to reveal anything conclusive, an intrepid officer asked the neighborhood garbage collector to turn Greenwood's garbage over to her instead of disposing of it. ${ }^{138}$ The officer's search of the garbage yielded various items indicative of narcotics use. This information helped the officer to secure a warrant, and a search of Greenwood's home turned up quantities of hashish and cocaine. ${ }^{139}$

Once again, the Court applied the Katz test to determine whether Greenwood had exhibited an expectation of privacy with respect to the trash, and if so, whether society would consider such an expectation to be objectively reasonable. With regard to the first prong, the Court believed that Greenwood had exhibited an expectation of privacy in his

134. Id. at 238 .

135. Id. at 236 .

136. Id. at 238.

137. 486 U.S. 35 (1988).

138. Id. at 37 .

139. Id. at $37-38$. 
garbage by placing it on the street in sealed opaque bags for a limited period of time for collection and disposal. ${ }^{140}$ Thus, the Court conceded that Greenwood did not expect the contents of the garbage bags to become known to the police or public. ${ }^{141}$

With regard to the second inquiry, however, the Court held that Greenwood's expectation was not objectively reasonable. ${ }^{142}$ Greenwood and his co-defendants made the same mistake as Smith, who exposed his phone records to the telephone company, ${ }^{143}$ and Ciraolo ${ }^{144}$ and Dow Chemical, ${ }^{145}$ who exposed their activities to the air:

[R]espondents exposed their garbage to the public sufficiently to defeat their claim to Fourth Amendment protection. It is common knowledge that plastic garbage bags left on or at the side of a public street are readily accessible to animals, children, scavengers, snoops, and other members of the public. Moreover, respondents placed their refuse at the curb for the express purpose of conveying it to a third party, the trash collector, who might himself have sorted through respondents' trash or permitted others, such as the police, to do so. Accordingly, having deposited their garbage "in an area particularly suited for public inspection and, in a manner of speaking, public consumption, for the express purpose of having strangers take it," respondents could have had no reasonable expectation of privacy in the inculpatory items that they discarded. ${ }^{146}$

Although Greenwood was consistent with the Court's prior decisions, the Court also made the same analytical mistakes. Once again, the Court labeled subjective privacy expectations unreasonable purely because the Court could "conceive of a scenario under which a member of the public might observe that which the targeted individual seeks to keep private." 147 Thus, to avoid "knowing exposure" of an activity one wishes to protect, one must guard against any potential exposure to a member of the public, no matter how improbable that exposure may be.

This philosophy is highly troubling in at least two respects. First, on a prudential level, it is difficult to believe that the Court wishes to

140. Id. at 39 .

141. Id.

142. Id. at 40.

143. See supra notes $88-98$ and accompanying text.

144. See supra notes 121-129 and accompanying text.

145. See supra notes $130-136$ and accompanying text.

146. Greenwood, 486 U.S. at $40-41$ (footnotes and citations omitted) (quoting United States v. Reicherter, 647 F.2d 397, 399 (3d Cir. 1981)).

147. See Serr, supra note 20, at 619. As Justice Brennan pointed out in dissent, "[t]he mere possibility that unwelcome meddlers might open and rummage through the containers does not negate the expectation of privacy in their contents any more than the possibility of a burglary negates an expectation of privacy in the home." Greenwood, 486 U.S. at 54 (Brennan, J., dissenting). 
promote a vision of society where citizens must presume their activities will be exposed to the police and where they must take consistent and dramatic steps to veil their activities from all potentially prying eyes. Dow Chemical's last remaining option was to erect a tarpaulin or other covering over its 2,000 acres of exposed property. ${ }^{148}$ Must citizens be forced to erect a similar shield around their own lives? ${ }^{149}$ Second, on a practical level, it is difficult to understand how any citizen could ever accomplish this task, particularly in our society where the increasing availability of and dependence on technology serve to make selfinsulation a seemingly impossible goal. As it turns out, the thermal imaging cases provide an excellent canvas on which to examine these concerns.

\section{III}

\section{Thermal Imagery: The Latest Challenge}

It is in this context of increased deference to law enforcement that the lower courts began grappling with the use of thermal imaging devices. United States $v$. Penny-Feeney ${ }^{150}$ was the first case to consider the Fourth Amendment implications of thermal imagers. Five years later, the case remains the spiritual grandparent of succeeding cases, most of which have relied on its analytical structure and, to some extent, its factual findings regarding the capabilities of the devices in reaching their own conclusions.

\section{A. Penny-Feeney Sets the Stage}

In Penny-Feeney, the police in Kona, Hawaii received information from multiple informants that Janice Penny-Feeney and her husband, Sean Feeney, were maintaining a large indoor marijuana growing operation at their residence. ${ }^{151}$ The informants provided a detailed description of the physical appearance of the defendants, their home, and the process by which they were growing marijuana in the garage. An

148. See supra note 133 and accompanying text.

149. At least one of the more conservative Justices on the current Court has expressed discomfort with this interpretation:

[E]ven individuals who have taken effective precautions to ensure against ground-level observations cannot block off all conceivable aerial views of their outdoor patios and yards without entirely giving up their enjoyment of those areas. To require individuals to completely cover and enclose their curtilage is to demand more than the "precautions customarily taken by those seeking privacy."

Florida v. Riley, 488 U.S. 445, 454 (1989) (O'Connor, J., concurring) (quoting Rakas v. Illinois, 439 U.S. 128, 152 (1978) (Powell, J., concurring)).

150. 773 F. Supp. 220 (D. Haw. 1991), aff'd on other grounds sub nom. United States v. Feeney, 984 F.2d 1053 (9th Cir. 1993).

151. Id. at 222 . 
officer drove by the defendants' home and visually confirmed that the defendants and their house matched the descriptions given by the informants. ${ }^{152}$

The officer subsequently rented a helicopter and flew over the defendants' residence with a FLIR, attempting to determine whether any unusual heat patterns indicated the presence of an indoor marijuana operation. The FLIR indicated that an inordinate amount of heat was escaping from the garage, but not from any other areas of the residence. After discussing the heat readings with the helicopter pilot, whose company owned the FLIR, the officer concluded that the readings were consistent with marijuana cultivation. ${ }^{153}$

Based on a warrant affidavit prepared by the officer, which contained readings from the FLIR as well as the information provided by the informants, the court issued a search warrant. The police subsequently discovered an extensive marijuana growing operation in the defendants' garage, including almost 250 marijuana plants, ten 1000-watt light bulbs, air conditioning units for ventilation, sophisticated irrigation systems, and an electric meter that had been altered to show a low consumption of electricity. ${ }^{154}$

At trial, the defendants contended the warrantless FLIR inspection of their residence by the police constituted a search in violation of the Fourth Amendment. ${ }^{155}$ The district court evaluated this claim using Katz's two-step expectation of privacy test. In the court's opinion, because the FLIR did no more than gauge the amount of heat emanating from the home, the question was whether the defendants had a legitimate expectation of privacy in this heat. ${ }^{156}$ With respect to Katz's subjective prong, the court found that the defendants had not attempted to impede the heat's escape from the garage, and in fact had used exhaust fans to vent the heat outside. ${ }^{157}$ This led the court to characterize the heat as "heat waste" or "abandoned heat." 158 Since the defendants had voluntarily abandoned this heat outside where "it could be exposed to the public," the court held the defendants had not manifested a subjective expectation of privacy in this heat. ${ }^{159}$

In considermg the objective prong, the district court held that even if the defendants had manifested an expectation of privacy in the heat, that expectation was not one society was prepared to recognize as

152. Id. at 223 .

153. Id. at $223-24$.

154. Id. at 224 .

155. Id. at 225 .

156. Id. at $225-26$.

157. Id. at 226.

158. Id. at 225.

159. Id. at 226. 
reasonable. In supporting this conclusion, the court first analogized the FLIR search to the garbage search found reasonable in California $v$. Greenwood. ${ }^{160}$ Just as the homeowner in Greenwood disposed of his trash in an area exposed to the public, so did the defendants expose their heat to the public by venting it outside their home. Thus, the court did not find the use of the FLIR, an "extra-sensory, non-intrusive"161 device, to be qualitatively different from the manual inspection of an opaque trash bag held by the Supreme Court not to constitute a Fourth Amendment search. ${ }^{162}$

The district court also compared the FLIR to a dog sniff, an activity the Ninth Circuit had ruled was not an illegal search in United States $v$. Solis. ${ }^{163}$ Like a dog sniff, the court found the use of a FLIR to be inoffensive and non-invasive, causing no embarrassment to the subject of the inspection. In addition, the court believed that heat and odors were analogous: "Heat emanations, the target here, are comparable to the odor emanations in Solis since they constitute a physical fact indicative of possible crime, not protected communications."164

Finally, the fact that the search had been conducted from a helicopter flying over the defendants' property did not render the search unreasonable. The district court cited the Supreme Court opinions California v. Ciraolo ${ }^{165}$ and Florida v. Riley, ${ }^{166}$ which upheld aerial searches of homes from a plane and a helicopter. As in Ciraolo and Riley, the FLIR observation was physically unobtrusive, causing no physical invasion of the home or curtilage:

[The officer] did no more than aim a passive infrared instrument at defendants' house from an aerial vantage point for the purpose of detecting disposed heat on the exterior of the house. No intimate details connected with the use of the home or curtilage were observed, and there was no undue noise, no wind, dust, or threat of injury. ${ }^{167}$

160. 486 U.S. 35 (1988); see supra notes 137-146 and accompanying text.

161. Penny-Feeney, 773 F. Supp. at 223, 226.

162. Id.

163. 536 F.2d 880 (9th Cir. 1976). The United States Supreme Court held a dog sniff of luggage in an airport was not a search in United States v. Place, 462 U.S. 696 (1983). The Supreme Court has not, however, considered whether this analysis would extend to a dog sniff of an individual's residence, where privacy expectations are the most heightened. In United States $\nu$. Thomas, 757 F.2d 1359 (2d Cir. 1985), the Second Circuit considered exactly that question. Rejecting the holding of the Ninth Circuit in Solis, the Second Circuit held that a dog sniff through the door of a residence to detect narcotics constituted a search: "[T]he defendant had a legitimate expectation that the contents of his closed apartment would remain private, that they could not be 'sensed' from outside his door. Use of the trained dog impermissibly intruded on that legitimate expectation." Id. at 1367.

164. Penny-Feeney, 773 F. Supp. at 227.

165. 476 U.S. 207 (1986).

166. 488 U.S. 445 (1989).

167. Penny-Feeney, 773 F. Supp. at 228. 
Because neither the subjective nor the objective prong of the Katz test was met, the court held that the use of the FLIR was not a Fourth Amendment search, and denied the defendants' motion to suppress the evidence derived from that search. ${ }^{168}$

\section{B. Criticism of the Penny-Feeney Decision}

Reaction to the Penny-Feeney decision has been mixed. Some courts have embraced the analysis of the case in its entirety, finding on similar facts that neither the subjective nor the objective prong of the Katz test has been met. These courts have also accepted the analogies of FLIRs to both garbage searches and dog sniffs. ${ }^{169}$ At the opposite extreme, other courts have rejected Penny-Feeney and found on similar facts that defendants had exhibited a reasonable expectation of privacy. ${ }^{170}$ Still other courts have fallen somewhere in the middle. ${ }^{171}$

There are three principal criticisms of Penny-Feeney and its successor cases: that courts have underestimated the intrusive potential and sophistication of FLIR technology, that the analogy to trash searches fails, and that the analogy to dog sniffs for narcotics fails. Commentators $^{172}$ and the few courts that have held the use of FLIRs to constitute an illegal search have made these criticisms eloquently. ${ }^{173}$ I will briefly examine each criticism in turn.

\section{The Assumption That FLIRs Are A Nonintrusive Technology}

Somewhat surprisingly, most courts have found thermal imagers to be a nonintrusive technology. In Penny-Feeney, the court described thermal imagers as

passive, non-intrusive instrument[s] which detect[] differences in temperature on the surface of objects being observed. [They] do[] not send any beams or rays into the area on which [they are] fixed or in any way penetrate structures within that area.... [T] he FLIR [was used] to observe the exterior of the

168. Id. at $228,230$.

169. See, e.g., United States v. Myers, 46 F.3d 668 (7th Cir.), cert. denied, 116 S. Ct. 213 (1995); United States v. Pinson, 24 F.3d 1056 (8th Cir.), cert. denied, 115 S. Ct. 664 (1994); United States v. Ford, 34 F.3d 992 (11th Cir. 1994).

170. See, e.g., State v. Young, 867 P.2d 593 (Wash. 1994) (finding a violation under both the United States and Washington state constitutions); see also United States v. Cusumano, 83 F.3d 1247, 1251 (10th Cir. 1996) (en banc) (McKay, J., dissenting) (arguing that FLIRs should require a warrant for their use).

171. See United States v. Ishmael, 48 F.3d 850 (5th Cir.) (finding defendants had manifested a subjective expectation of privacy, but refusing to recognize that expectation as reasonable), cert. denied, 116 S. Ct. 74 (1995).

172. See authors cited supra note 6 .

173. Young, 867 P.2d at 602-04; Cusumano, 83 F.3d at 1258-65 (McKay, J., dissenting). 
Penny/Feeney abode [and] did no more than gauge and reflect the amount of heat that emanated therefrom. ${ }^{174}$

This description of thermal imagers' capabilities has been echoed by the circuits that subsequently have held the use of the devices not to implicate the Fourth Amendment. ${ }^{775}$ The Fifth and Seventh Circuits have both held that a thermal imaging scan "does not intrude in any way into the privacy and sanctity of a home." 176 More explicitly, the Eleventh Circuit has stated that a FLIR is "of such low resolution as to render it incapable of revealing... intima[te]... detail" such as human conversations or activities. ${ }^{177}$

These assumptions have been hotly disputed. In State v. Young, ${ }^{178}$ the Washington Supreme Court provided a very different picture of the technological capabilities of thermal imagers. In a detailed discussion of FLIRs, the court found that these devices can, under certain circumstances, detect the presence of a person standing next to a curtained window or behind a wall made of a thin material such as plywood, in effect "see[ing] through the walls of the home."179 The police can use FLIRs to detect what rooms a homeowner is heating (and thus occupying) at night, and what rooms contain heat-producing appliances. ${ }^{180}$ This allows the police to make inferences about a variety of activities occurring within the home.

As the dissenting judges described in the Tenth Circuit opinion of United States v. Cusumano, ${ }^{181}$ activities that generate a significant amount of heat produce a detectable "heat signature" which a thermal imager might be able to resolve into indistinct images under certain conditions. ${ }^{182}$ Some FLIRs are sensitive enough to identify the heat generated by a heart beat. ${ }^{183}$ In fact, during the siege of the Branch

174. United States v. Penny-Feeney, 773 F. Supp. 220, 228 (D. Haw. 1991), aff'd on other grounds sub nom. United States v. Feeney, 984 F.2d 1053 (9th Cir. 1993).

175. Ishmael, 48 F.3d at 855-56; United States v. Myers, 46 F.3d 668 (7th Cir.), cert. denied, 116 S. Ct. 213 (1995); United States v. Pinson, 24 F.3d 1056 (8th Cir.), cert denied, 115 S. Ct. 664 (1994); United States v. Ford, 34 F.3d 992 (11th Cir. 1994).

176. Ishmael, 48 F.3d at 856 (quoting Myers, 46 F.3d at 670).

177. Ford, 34 F.3d at 996.

178. 867 P.2d 593 (Wash. 1994).

179. Id. at 598 .

180. Id.

181. 83 F.3d 1247 (10th Cir. 1996) (en banc) (McKay, J., dissenting).

182. Id. at 1257 (McKay, J., dissenting). Military-grade thermal imagers already have this capability, and as the Cusumano dissent recognized, it is "only a matter of time before such capabilities trickle down to law enforcement." Id. at 1257 n.12 (McKay, J., dissenting).

183. Moore, supra note 6 , at 810 . 
Davidian complex in Waco, Texas, the FBI used FLIRs to determine whether specific rooms were occupied. ${ }^{184}$

While local police departments are more likely to own a lesssophisticated, hand-held or helicopter-mounted thermal imager costing about $\$ 100,000$ rather than the $\$ 500,000$ imaging systems used by the military, ${ }^{185}$ this does not render the use of less-sophisticated FLIRs inherently reasonable under the Fourth Amendment. As the dissenting judges wrote in Cusumano:

The government contends that this device is incapable of resolving images through the walls of a home and in fact does little more than identify hot spots on the exterior of a building. While such reassurances are comforting, I anticipate that this comfort will be ephemeral. It is in the nature of technology to improve, and I doubt that infrared technology is uniquely static.... I trust that the government would, in most instances, employ a more capable imager with discretion; nonetheless, the very existence of such discretion would run afoul of the Constitution. ${ }^{186}$

Moreover, any government assertion (such as that made in Cusumano) that the devices are not particularly useful or sophisticated, and thus unintrusive, rings hollow; why else would law enforcement be using them (with such success) to detect indoor marijuana grows?

\section{The "Heat Waste" Analogy}

Most courts finding that FLIR use does not constitute a search have analogized the devices to the warrantless garbage inspection upheld by the Supreme Court in California v. Greenwood. ${ }^{187}$ These courts have conceptualized heat emissions resulting from indoor marijuana cultivation as "waste," similar to the narcotics waste products Greenwood discarded in his curbside garbage bags. ${ }^{188}$ This argument rests, in part, on the fact that marijuana growers often intentionally vent excess heat outside their homes using fans and air conditioning units. ${ }^{189}$ Since society does not recognize as reasonable an individual's expectation of privacy

184. Id. at 810-11. And many will remember the fascinating scene in the movie PAtRIOT GAMES (Paramount Pictures 1994), where the Central Intelligence Agency used thermal technology on an orbiting satellite to monitor a nighttime gun battle in North Africa.

185. See Mitzman, supra note 48 (describing the range in price and sophistication of thermal imaging systems manufactured by FLIR Systems, Inc.).

186. Cusumano, 83 F.3d at 1259-60 (McKay, J., dissenting).

187. 486 U.S. 35 (1988).

188. See, e.g., United States v. Myers, 46 F.3d 668, 670 (7th Cir.), cert. denied, 116 S. Ct. 213 (1995); United States v. Pinson, 24 F.3d I056, 1058-59 (8th Cir.), cert. denied, I15 S. Ct. 664 (1994); United States v. Ford, 34 F.3d 992, 997 (11th Cir. 1994).

189. See, e.g., Pinson, 24 F.3d at 1057-58 (discussing how the defendants vented excess heat to maintain proper growing temperature). 
in such waste products voluntarily exposed to the public, a FLIR inspection of "heat waste" is not subject to Fourth Amendment scrutiny. ${ }^{190}$

The analogy to garbage searches, however, ignores an important fact underlying the Greenwood decision: that individuals who place garbage outside their homes assume the risk that children, scavengers, trash collectors and other members of the public may sort through it. ${ }^{191}$ However, even an individual who vents heat outside her home can hardly be viewed as depositing garbage "in an area particularly suited for public inspection."192 Members of the public (or trash collectors) may at times sort through trasn, but they do not roam the streets conducting thermal scans of their neighbors' homes.

Moreover, even if heat is vented to the outside, a FLIR detects all heat emanations from a home, not just the heat voluntarily expelled..$^{193}$ The only way for a person to truly avoid the risk of exposing their heat to a FLIR would be to turu off all heat sources from within the home. ${ }^{194}$ Superman's ice-constructed Fortress of Solitude would be protected, but apparently not much else. It is fair to assume that such a drastic method of self-protection is one that no reasonable court would suggest. Lacking the "voluntary" nature of the trash disposal in Greenwood, and not posing the risk that the public regularly detects heat emissions the way they may find articles in the trash, the "heat waste" analogy fails.

\section{The "Dog Sniff" Analogy}

Penny-Feeney also analogized thermal imagers to the use of drugsniffing dogs to detect narcotics inside a home, a technique upheld by the Ninth Circuit in United States v. Solis. ${ }^{195}$ The use of Solis as authority is flawed in two respects. First, in United States v. Place, the Supreme Court only upheld dog sniffs of luggage at airports, ${ }^{196}$ a far different context from that presented in Solis, where a dog entered private property to sniff a publicly parked semi-trailer for narcotics from one foot away. ${ }^{197}$ At least one circuit has rejected the extension of war-

190. See, e.g., Myers, 46 F.3d at 670 .

191. Greenwood, 486 U.S. at 40-41.

192. Id. (quoting United States v. Reicherter, 647 F.2d 397, 399 (3rd Cir. 1981)).

193. State v. Young, 867 P.2d 593, 603 (Wash. 1994); see also United States v. Cusumano, 83 F.3d 1247, 1264 (10th Cir. 1995) (en banc) (McKay, J., dissenting) ("Heat loss and heat conduction (or radiation) obey the laws of physics and are not phenomena over which an individual customarily exerts control. An individual no more chooses to have his or her home emit infrared radiation than she or he chooses to absorb or reflect visible light, but we have never heard the process of sight described in terms of abandoned photons." (footnotes omitted)).

194. Young, 867 P.2d at 603 .

195. 536 F.2d 880 (9th Cir. 1976); see supra notes 163-164 and accompanying text.

196. 462 U.S. 696 (1983).

197. See Solis, 536 F.2d at 881 . 
rantless dog sniffs of the home upheld in Solis, arguing that a dog sniff "that is not intrusive in a public airport may be intrusive when employed at a person's hoine." 198 Thus, Place and Solis cannot be extended cavalierly to thermal imagery conducted on one's residence, an area long recognized to deserve the highest constitutional protection. ${ }^{199}$

Second, as the Court recognized in Place, a dog sniff is fairly unobtrusive because it only detects the presence or absence of contraband. ${ }^{200}$ It does not disclose an individual's brand of toothpaste, color of underwear, or type of reading material, all of which would be exposed if the police were to open and search a subject's luggage. Thus, the Court expressly found a dog sniff to be sui generis, distinguishable from other investigative procedures by the limited information it provides. $^{201}$

Rather than focusing on the unique nature of dog sniffs, PennyFeeney and its successors have likened FLIR inspections to dog sniffs because both procedures cause minimal embarrassment to the subject. ${ }^{202}$ A dog sniff obviates the need to open luggage; a FLIR imspection obviates the need to search a house physically. The mere fact that a particular search technique causes minimal einbarrassment, however, is not sufficient grounds to jettison Fourth Amendment protection. Unlike a dog sniff, which only detects contraband, a thermal imager detects heat emanations-data that has no inherent "contraband" aspect. Unusual heat emanations from a garage or basement are consistent with innumerable perfectly legal activities, ranging from growing African violets ${ }^{203}$ to operating a pottery kiln..$^{204}$ Thus, the analysis advanced by the Supreme Court in Place and Solis cannot be extended to justify the warrantless use of thermal imagers on the assumption that FLIRs are no more intrusive than dog sniffs.

198. United States v. Thomas, 757 F.2d 1359, 1366 (2d Cir. 1985); see supra note 163 and accompanying text.

199. See Oliver v. United States, 466 U.S. 170, 178 (1984) (discussing the Court's "overriding respect for the sanctity of the home" (quoting Payton v. New York, 445 U.S. 573, 601 (1980)); see also infra notes 236-239 and accompanying text.

200. Place, 462 U.S. at 707.

201. Id. The Court learned only one year later that a dog sniff was not as "sui generis" as it thought. In United States $v$. Jacobsen, the Court upheld a warrantless field chemical test of a white, powdery substance because the test revealed only whether the substance was cocaine; if it was not cocaine, the test did not determine whether it was sugar, flour or talcum powder. 466 U.S. 109, 12223 (1984). Although research is being conducted into other techniques that detect the presence of contraband only, see infra notes 253-254 and accompanying text, dog sniffs and narcotics field tests are the only such techniques the Court has yet considered.

202. United States v. Penny-Feeney, 773 F. Supp. 220, 227 (D. Haw. 1991), aff'd on other grounds sub nom. United States v. Feeney, 984 F.2d 1053 (9th Cir. 1993).

203. United States v. Cusumano, 83 F.3d 1247, 1264 n.33 (10th Cir. 1996) (en banc) (McKay, J., dissenting).

204. Steele, supra note 6 , at 32 . 
IV

Fourth Amendment Values and the Use of Technology IN LAW ENFORCEMENT: A DOUBLE-EDGED SWORD

As we have seen, the cornerstone of Fourth Amendment analysis is whether a person has a "constitutionally protected reasonable expectation of privacy." 205 In determining the "legitimacy" of a privacy expectation in a given case, the Court has considered various questions, such as whether an individual has "knowingly exposed" his or her activity to the public and whether the activity can be detected from a public vantage point. In Oliver $v$. United States, the Supreme Court boiled the test of legitimacy down to a single pithy, yet circular question: "whether the government's intrusion infringes upon the personal and societal values protected by the Fourth Amendment." ${ }^{206}$ As the cases discussed in Parts II and III demonstrate, however, no clear test of legitimacy has emerged from the Court's Fourth Amendment jurisprudence-a jurisprudence that has often obscured, rather than clarified, what these core personal and societal values are.

Both the Supreme Court and commentators agree that the framers of the Constitution designed the Fourth Amendment to abolish the use of the British "general warrant" and its American colonial counterpart, the "writ of assistance."207 General warrants and writs of assistance were notable for their intrusiveness, their arbitrariness, their suppression of free thought, and their invasion of the home. ${ }^{208}$ The writ of assistance, for example, authorized officials to search anywhere in an individual's home or place of business if officials suspected the individual had failed to pay customs duties. ${ }^{209}$

The Court's opinions have long expounded values consistent with the banning of general warrants over 200 years ago. In the 1886 case of Boyd v. United States, ${ }^{210}$ the Court stated that it was "not the breaking of [the defendant's] doors, and rummaging of his drawers, that constitutes the essence of the offense; but it is the invasion of his indefeasible right of personal security [and] personal liberty." 211 The Court has affirmed that individual privacy and security are two values basic to a free society. ${ }^{212}$ Justice Harlan, architect of the Court's current

205. Oliver v. United States, 466 U.S. 170, 177 (1984) (quoting Katz v. United States, 389 U.S. 347, 360 (1967) (Harlan, J., concurring)).

206. Id. at $182-83$.

207. David E. Steinberg, Making Sense of Sense-Enhanced Searches, 74 MinN. L. Rev. 563, 574 n.45, 575 (1990).

208. DiPippa, supra note 28, at 514.

209. Steinberg, supra note 207 , at 574 n. 45 .

210. 116 U.S. 616 (1886), overruled on other grounds by United States v. Doe, 465 U.S. 605

(1984).

211. Id. at 630 .

212. Camara v. Municipal Court, 387 U.S. 523, 528 (1967). 
privacy framework, has declared that the warrant requirement aims to "secure a measure of privacy and a sense of personal security throughout our society."213

While most recognize that the Fourth Amendment affords all persons in the United States certain protections, our common-sense notion of the Fourth Amendment is that, at bottom, it is a tool to protect ordinary citizens from arbitrary and unreasonable government encroachment into their personal lives. As such, an important factor in determining the constitutionality of a particular police search technique is its impact on law-abiding citizens. ${ }^{214}$ However, as a tool for protecting personal privacy, preserving personal security, and safeguarding the rights of law-abiding citizens, technology is a double-edged sword.

On the "plus" side, technological advancements show great promise as a means to assist law enforcement officers in their efforts to fight crime. The annual cost of crime and crime prevention in the United States runs into the hundreds of billions of dollars. ${ }^{215}$ In an era of strained budgets and spiraling crime, ${ }^{216}$ technology offers a costeffective means to reduce crime and increase police productivity. ${ }^{217}$ Soft body armor, advanced fingerprinting devices, and DNA identification are all relatively recent technological advances that have helped the police to achieve such gains. ${ }^{218}$

In addition to reducing the cost of crime and crime prevention, technology also provides methods of crime control that offer greater protection for the law-abiding public. The National Institute of Justice is developing technology that is capable of either "tagging" or stopping cars remotely in order to avoid "hot" high-speed police pursuits, which can put law-abiding bystanders at risk. ${ }^{219}$ The Institute also seeks to develop a weapon that can recognize its owner so that only he or she

213. United States v. White, 401 U.S. 745, 790 (1971) (Harlan, J., dissenting).

214. See Amold H. Loewy, The Fourth Amendment As a Device for Protecting the Innocent, 81 Mich. L. REv. 1229 (1983). Loewy argues that the Court's primary focus in Fourth Amendment cases "should be on the effect of its pronouncements on the innocent." Id. at 1230. He contends that the guilty should be able to invoke the Amendment only when necessary to protect the innocent. Id. at 1248. Thus, he suggests that an all-powerful "divining rod" that could detect only evidence of a crime-sort of a turbocharged dog sniff-would be the perfect tool for the police to ferret out crime, because the impact on ordinary citizens would be minuscule. Id. at 1244. It is true that such devices might well be preferable to thermal imagers and similar devices that have the unfortunate tendency to detect evidence of non-criminal as well as criminal activity. As I discuss in the text above, however, such devices are not without their own troubling side effects.

215. See Defense Technology, Reinvestment and Conversion Issues: Hearings Before the Subcomm. on Research and Technology of the House Comm. on Armed Services, 103rd Cong., $2 \mathrm{~d}$ Sess. 148 (1994) (statement of David G. Boyd, Director, Science and Technology Division, National Institute of Justice, Department of Justice).

216. See id. at 149 .

217. See id. at 150 .

218. Id. at 150-51.

219. Id. at 152 . 
can fire it. ${ }^{220}$ A top priority for the Institute continues to be the development of a "sinart gun detector," which would allow the police to detect concealed weapons on a person without revealing any other information about what he or she is carrying. ${ }^{221}$

On the "minus" side, many search technologies provide inuch more comprehensive and detailed information than, for example, a smart gun detector. Most search technologies, thermal imagers included, allow the police to search undetected from afar, and to amass information that may have little to do with the crime under investigation.

This capability has two principal effects. First, technology alters our intuitive sense of the boundaries of perception. Unlike a telescope or camera, which enhances our eyesight, or a dog sniff, which auginents our sense of smell, devices such as thermal imagers do not correspond to our natural senses. ${ }^{222}$ Rather, such search technologies can provide a user with the means to both discover and interpret data in a way no traditional sense-enhanced search can provide. For example, while humans lack the ability to see infrared radiation, thermal imagers can take a snapshot of heat patterns and translate that information into a visual picture from which we can draw inferences about human activity. In addition, while we can detect rough gradations of heat with our sense of touch, our tactile sense lacks a FLIR's sensitivity to detect temperature differentials of 0.2 degree centigrade. Most significantly, even with our unfocused ability to detect heat, ordinary human perception has definable limits. We cannot walk up to a home, touch the wall, and form a conclusion as to whether there is. a hydroponics operation inside. Technology allows us effectively to hop over that wall and see what is on the other side. Thus, technology dramatically extends the boundaries of what we can perceive.

Second, technology can shape, alter, and ultimately diminish citizens' privacy expectations over time. Once, individuals could reasonably expect that when they arrived home and closed their doors, the police would not be able to enter without a warrant. Now, technologyenhanced searches allow the police to sidestep such expectations. In an era when devices such as thermal innagers are common, citizens can no longer be assured that their seemingly private activities are actually private.

This has several inplications for the law-abiding population. First, the recognition that the government has the discretion and the ability to

220. Id. at 151.

221. See id. at 152; see also David A. Harris, Superman's X-Ray Vision and the Fourth Amendment: The New Gun Detection Technology, 69 TeMp. L. REv. 1 (1996).

222. Lisa J. Steele, The View From On High: Satellite Remote Sensing Technology and the Fourth Amendment, 6 HiGH TECH. L.J. 317, 331 (1991). 
invade one's privacy, often without alerting the subject, will ultimately serve to diminish the citizenry's privacy expectations. This reduction has high social costs. ${ }^{223}$ It causes law-abiding citizens to fear government surveillance because they cannot know when they are under investigation. ${ }^{224}$ It can chill the willingness of individuals to exercise their First Amendment rights. ${ }^{225}$ It forecloses the public knowledge that accompanies a traditional physical search, thereby reducing police accountability. ${ }^{226}$ Some commentators simply have pointed out the fundamental unfairness of being watched without an opportunity to notice the watcher. ${ }^{227}$ All these costs apply as strongly to the law-abiding citizen we are trying to protect as they do to the guilty criminal. ${ }^{228}$

Second, as technology-enhanced searches become more common, and people become cognizant of the relative ease with which the government can invade their privacy and personal space, citizens will be forced to take more extreme measures to insulate themselves from the outside world. ${ }^{229}$ In the past, citizens could often rely on property to be their bulwark against state intrnsion. To escape the outside world, one simply had to close the front door and retreat behind the walls of the home. Today, it is increasingly difficult to develop spheres of autonomy and personal privacy. As citizens become aware of the looming possibility of a police fly-over, they may feel the need to cover their curtilage. They may desire to insulate their homes to protect against ever-more-sophisticated thermal imagers. They may be reluctant to attend a controversial political demonstration if they know the government may take satellite photographs of the proceedings. Technology has made it much more difficult for citizens to "shut the door" against government intrusion.

While these scenarios may seem improbable today given the state of technology-enhanced surveillance, they will become increasingly realistic as the technology becomes more sophisticated. Although pen registers, tracking devices, and helicopter fly-overs do not currently require warrants, we may fairly say that the police rarely initiate such surveillance unless they possess some information tending to inculpate a particular suspect. Such has been the situation with thermal imagers, where the police have nearly always received information such as an informant's tip or a call from the power company complaining of un-

223. Steinberg, supra note 207 , at $570-71$.

224. Id.

225. See United States v. United States Dist. Court, 407 U.S. 297, 313-14 (1972) (discussing how undisclosed searches can have a chilling effect on the exercise of First Amendment rights).

226. Steinberg, supra note 207, at 572-73.

227. Steele, supra note 222 , at 328.

228. See Loewy, supra note 214, at 1230.

229. See supra note 149 and accompanying text. 
usually high power usage before conducting thermal surveillance. However, we should not be confident that this cozy state of affairs will persist forever. As police technologies become more sophisticated, less costly, and more generally available to law enforcement officers, we can reasonably expect that all of us will become more susceptible to government surveillance, even absent some initial "trigger" such as an informant's tip. In addition, as citizens learn of such expanding government powers, they will naturally seek ways to insulate themselves from that power. One does not have to be engaged in criminal activity to be unnerved by the likelihood of pervasive government surveillance.

Moreover, as broader use of technology causes privacy expectations to decline, we will see an increasing tension within the Katz framework. Many of the post-Katz cases emphasize that subjects are or should be aware that their activities are exposed to public view. For example, in Smith v. Maryland, the Court upheld the use of pen registers partly because telephone subscribers know the numbers they call are not secret because they are listed on their monthly bill..$^{230}$ As the government gains the power to amass more and more information about its citizens and their activities, and as citizens learn of that power, declining privacy expectations become more troubling.

Satellite technology provides a good example. Suppose that scientific and commercial surveillance of a particular region became prevalent, perhaps for environmental monitoring. Further suppose that the residents of the region were aware of that surveillance. Could the government then argue that citizens living in that region have a diminished expectation of privacy? ? $31^{3}$ One would hope not, but neither Smith nor Dow Chemical (the latter of which suggests that the Court might not permit such warrantless satellite surveillance ${ }^{232}$ provides a satisfying answer to such questions. One can imagine an Orwellian spiral in which increased surveillance causes diminished privacy expectations, which legitimize further surveillance, and on and on-until the entire Fourth Amendment unravels.

Recall the brief discussion about writs of assistance at the beginning of this Part. The writs were denounced because they were intrusive, arbitrary, tended to suppress free thought, and permitted wide-ranging invasions of the home. ${ }^{233}$ Technology-enhanced surveillance poses strikingly similar dangers to the law-abiding public. Despite the promise of technology for reducing crime and targeting only the guilty, it simultaneously increases citizens' need to protect themselves from state

230. Smith v. Maryland, 442 U.S. 735,742 (1979).

231. See Steele, supra note 222, at 329.

232. Dow Chem. v. United States, 476 U.S. 227, 238 (1986).

233. See text accompanying note 208. 
invasion while decreasing their ability to protect against that invasion. The question is how the Court should evaluate technology-based search techniques so as to avoid these dangers.

\section{$\mathrm{V}$ \\ GuIdEPosts For the COURT: Evaluating EMERgING \\ TECHNOLOGIES UNDER THE COURT'S \\ PRIVACY FRAMEWORK}

As it confronts new technologies in the future, the Court must be guided by the values that underlie the Fourth Amendment: protection of personal security, preservation of individual privacy, and shielding of law-abiding citizens from excessive government intrusion. As we have seen, technology can threaten to undermine these values and exact a cost from the innocent public in ways that the Court has largely ignored.

All is not lost, however. The Supreme Court's post-Katz decisions may not be entirely coherent, but they do provide a measure of hope for the typical citizen who wants both the benefit of an efficient police force and the ability to preserve some measure of her own personal privacy. The criteria presented below work together to limit the government's ability to intervene in citizens' private lives without a warrant. These criteria are neither original nor new. In fact, they are repeated throughout the Supreme Court's post-Katz jurisprudence, although the Court's opinions are somewhat erratic in the degree to which they emphasize these criteria.

Most commentators view the Supreme Court's post-Katz cases, particularly those following the 1979 decision of Smith v. Maryland, as an unlikely foundation on which the Court might construct further constitutional constraints on the use of new law enforcement technologies. However, while I share many of the concerns commentators have expressed with respect to the Court's post-Katz case law, I believe those cases do provide strong ammunition for the Court to use to halt any further loosening of Fourth Amendment guarantees in the realm of technology-enhanced searches. ${ }^{234}$

In this Part, I attempt three interwoven tasks. First, I suggest that respect for the fundamental Fourth Amendment values of privacy, personal security, and protection of the law-abiding public, as well as sound policy and practical concerns, demand that thermal imagers be constitutionally proscribed absent a warrant. Second, I seek to prove that an

234. My approach does, of course, have a pragmatic aspect to it. It is unlikely that there are five Justices on the Court today who will seize the thermal imaging issue as a means to revisit the cases beginning with Smith v. Maryland that narrow the scope of the Fourth Amendment. See supra note 39. 
honest adherence to the logic of the post-Katz cases, as reflected in the four "guideposts" I describe below, should compel the Court to find that use of thermal imagers constitutes a Fourth Amendment search. ${ }^{235}$ Third, I attempt to make clear that the utility of these criteria is not limited to evaluating thermal imagers; rather, by taking into account the values, concerns, and ideals expressed in Part IV, they provide an excellent framework with which to evaluate any new search technology.

The four criteria the Court should consider when evaluating emerging search technologies are:

1) the area subject to surveillance;

2) the type of information the technology can disclose;

3) the level of public awareness surrounding the search technique; and

4) the nature and degree of intrusion that the technology can present.

No single one of these criteria will ever be sufficient to answer whether the technology at issue is a search; rather, these four factors are all relevant when examining a new technology, and a conclusion should be drawn from the sum of these four component parts. As this discussion will make clear, an evaluation of these criteria in the context of each new search technique will provide the Court with an effective tool to advance law enforcement interests while preserving the fundamental values that underlie the Fourth Amendment.

\section{A. The Area Subject To Surveillance}

The Supreme Court has applied sharply different levels of Fourth Amendment protection depending on the area being surveyed. The Court consistently has found that the home and curtilage "deserve the most scrnpulous protection from government invasion."236 In Oliver $v$. United States, the Court drew a sharp distinction between a home and its surrounding curtilage, which are generally subject to Fourth Amendment protection, and "open fields," which are not. ${ }^{237}$ Because "open fields" do not provide the setting for those "intimate activities" the Fourth Amendment aims to protect, an individual cannot claim a reasonable expectation of privacy in activities conducted in those areas. ${ }^{238}$ This contrasts sharply with the substantial protections afforded the home and its curtilage: "[T]he Court since the enactment of the Fourth Amendment has stressed 'the overriding respect for the sanctity of the

235. Portions of this framework are drawn from Wilkins, supra note 28.

236. Oliver v. United States, 466 U.S. 170, 178 (1984).

237. Id. at 178-79.

238. Id. at 179. 
home that has been embedded in our traditions smce the origims of the Republic." "239

The Court's technology cases also have emphasized this distinction. For example, in United States v. Knotts, a unanimous Court upheld the placement of a tracking device in a drum of chloroform in part because the beeper was not used to reveal the movements of the drum once inside the defendant's home. ${ }^{240}$ One year later, in United States $v$. Karo, the Court invalidated the monitoring of a beeper in a private residence because it revealed information about the interior of the premises. ${ }^{241}$ The same concern for the privacy of the home is found in Dow Chemical, where the Court found it particularly "important that [Dow's industrial plant] is not an area immediately adjacent to a private home, where the privacy expectations are most heightened."242

Clearly, the Court gives the most exacting scrutiny to police conduct that extracts information about activities taking place within one's home. As discussed in Part I, while thermal imagers only detect the surface temperature of objects such as walls and doors, this information allows the user to make a number of conclusions about the activities taking place behind those walls. This should weigh heavily against a finding that the warrantless use of FLIRs is constitutional. Thermal imagers, when focused on a home or barn suspected of harboring an indoor marijuana growing operation, detect information about the interior of the home and the other buildings on a suspect's property. FLIRs are not used by the police to uncover marijuana lying in the "open fields" nor to discover evidence of any other illegal activity taking place outdoors. ${ }^{243}$ Although the Penny-Feeney court argued that a FLIR only detects heat on the exterior of a subject's house, even Penny-Feeney recognized that the target was not the external heat itself, but "a physical fact indicative of possible crime" occurring within the household. ${ }^{244}$

Indeed, Katz rejected the notion that a physical invasion was necessary to invoke Fourth Amendment analysis, holding instead that the wiretap was unconstitutional because it detected Katz's conversation inside the phone booth. ${ }^{245}$ By providing data from which the police can

239. Id. at 178 (quoting Payton v. New York, 445 U.S. 573, 601 (1980)).

240. United States v. Knotts, 460 U.S. 276, 285 (1983); see supra notes 100-111 and accompanying text.

241. 468 U.S. 705, 715 (1984).

242. Dow Chem. Co. v. United States, 476 U.S. 227, 237 n.4 (1986).

243. One caveat: FLIRs have been used by the police to detect escaped prison convicts. See supra note 50 . However, this activity, taking place in outdoor public spaces, does not raise analogous Fourth Amendment concerns.

244. United States v. Penny-Feeney, 773 F. Supp. 220, 227-28 (D. Haw. 1991), aff'd on other grounds sub nom. United States v. Feeney, 984 F.2d 1053 (9th Cir. 1993).

245. Katz y. United States, 389 U.S. 347, 353 (1967). 
extrapolate information about activities occurring inside a home, thermal imagers raise analogous concerns. ${ }^{246}$

Thermal imagers thus aptly illustrate the danger that new search techniques can present to even such a long-recognized and widely accepted value as the sanctity of the home. While avoiding physical penetration, thermal imagers can collect data emanating from inside our most private sanctuaries. Respect for core Fourth Amendment values demands that the Court draw an informational as well as a physical line at the entrance to the home.

As discussed in Part II, the Supreme Court's jurisprudence prior to Katz largely interpreted the Fourth Amendment as a tool to protect against warrantless searches and seizures of tangible property. In certain circumstances, such as those presented by thermal imagers, traditional property interests should be preserved as a bulwark against state invasion. Inherent in the idea of personal property is a heightened societal commitment to privacy and autonomy, values that are reflected in the Fourth Amendment. Our collective social and moral judgment that the home is a refuge, an area protected from state invasion, should trump the fact that technological innovation now allows the police to "see" within the home without physically penetrating its walls. The Supreme Court's cases reflect a determination to protect the home that is entirely consistent with this perspective.

\section{B. The Nature of the Information Disclosed to the Police}

To ensure that the Fourth Amendment carries out one of its essential functions-the preservation of privacy and protection of the lawabiding public from intrusive and unwarranted government invasion-it should be interpreted in a manner that minimizes, as much as possible, the disclosure of information that has no bearing on crininal activity. The Supreme Court seems to agree. The Court has indicated that the nature and quantity of information that a surveillance technique can disclose is an important factor in determining whether the use of that technique constitutes a search. While the Court's record is inconclusive on this point (this is, after all, the same Court that upheld the warrantless inspection of phone records in Smith v. Maryland), ${ }^{247}$ a close examination of the post-Katz cases demonstrates that the Court is very reluctant to uphold warrantless search techniques that sweep broadly and disclose innocuous private information in addition to indicia of criminal activity.

246. See United States v. Cusumano, 83 F.3d 1247, 1257 (10th Cir. 1995) (en banc) (McKay, J., dissenting) ("I see no reason to blind ourselves to the physical reality of this relationship by severing our analysis of the heat differentials emanating through the walls of a structure from an informed consideration of the heat sources within that structure.").

247. 442 U.S. 735 (1979). 
In Dow Chemical, for example, the Court upheld the use of an aerial mapping camera to photograph Dow's industrial plant, in part because the photographs were not so revealing of "intimate details" as to raise constitutional concerns. ${ }^{248}$ The camera could photograph the outlines of the facility's buildings and equipment, but could not detect confidential discussions or activities occurring inside the buildings. ${ }^{249}$ In contrast, the use of the beeper in Karo was prohibited because it revealed the movement of a five-gallon can of ether within the defendant's home-"a critical fact about the interior of the premises that the Government...could not have otherwise obtained without a warrant."250

As discussed in Part III, thermal imagers are able to provide the police with "intimate details" concerning the interior of a residence. The rooms where people are present or the location of legal heatgenerating activities is information that the government has no right to learn. This conclusion should not be avoided by disingenuously reformulating the issue as whether an individual has a legitimate expectation of privacy in the heat itself. ${ }^{251}$

Moreover, unlike a dog sniff or a narcotics field test, a thermal imager reveals more than the presence or absence of contraband. ${ }^{252}$ This fact is all the more troubling because there is no way for a FLIR operator to utilize the device so as to "shut out" detection of extraneous information. Dogs do have the ability to detect odors other than drugs, but canine discretion is channeled by trainers who purposefully do not train narcotics dogs to alert to those odors. Current research into the construction of a "smart gun detector" attempts to mimic this aspect of a dog sniff. The devices, which passively will detect magnetic emissions from both lethal and nonlethal metallic objects, will contain software that will compare those emissions to pre-programmed "profiles" for different weapons, alerting the law enforcement user only if a profile is matched. ${ }^{253}$

248. Dow Chem. Co. v. United States, 476 U.S. 227, 238 (1986).

249. Id. at 238-39.

250. United States v. Karo, 468 U.S. 705, 715 (1984).

251. Compare United States v. Penny-Feeney, 773 F. Supp. 220, 226 (D. Haw. 1991) (holding that the proper question under Katz was whether the defendants had a legitimate expectation of privacy in their heat), aff $d$ on other grounds sub nom. United States v. Feeney, 984 F.2d 1053 (9th Cir. 1993), with United States v. Cusumano, 83 F.3d 1247, 1257 (10th Cir. 1995) (en banc) (McKay, J., dissenting) (focusing Fourth Amendment scrutiny on the information a "heat signature" discloses, not the heat itself).

252. See supra notes 196-204 and accompanying text.

253. Detection and Classification of Concealed Weapons Using Magnetic Gradient Measurements, Department of Justice Concealed Weapon Detection Project, Idaho NATIONAL ENGINEERING LABORATORY (on file with author). 
There is no similar way to restrict the information a thermal imager provides. The devices detect heat, and it is up to the operator of the FLIR, not a dog or a gun detector, to interpret that data to determine whether a marijuana grow is located inside a residence. In fact, the very training that allows a FLIR operator to make such determinations also gives him the proficiency to make other, more troubling conclusions about in-home activities.

Thus, thermal imagers stand in stark contrast to the devices that the Court has held do not implicate the Fourth Amendment-devices that do a better, although not ideal, job of providing evidence only of criminal activity, thereby proving much less of a threat to the law-abiding public. This is not to say that a perfect crime "divining rod," to use one commentator's term, ${ }^{254}$ is entirely free from concern. For example, I suspect that the indiscriminate application of a fictional "marijuanalocator" for prolonged periods on all person's homes in a particular community would cause significant fear, uncertainty, and resentment against the government. Such a device would exact too high a price from law-abiding citizens, even though they might have nothing to hide. The point, however, is that given the choice between a device such as a FLIR and a technology whose data can be more narrowly circumscribed, core Fourth Amendment values should always steer the government toward the use of the latter device.

\section{Public Awareness of Law Enforcement Technologies}

A main problem with technology is that it has the unfortunate tendency to invest the police with the power to conduct searches that are impossible for any citizen, guilty or innocent, to ward off. As we have seen, one way technologies provide this power is by giving the police the ability, via a wiretap, a beeper, a FLIR, or other such device, to uncover information that formerly could be protected behind a wall, a roof, or a closed door. Another troubling aspect to this power is that technology allows the police to conduct a search without the subject ever knowing she was the target of an investigation. Such searches have the potential to exact a particularly chilling toll on Fourth Amendment values.

At one end of the spectrum, we have well-recognized and pervasive technologies that include, for example, the cordless phone. Today, most cordless phone users are aware that their transmissions can be intercepted or "crossed" with other phones in their area. If they are not aware of this, they should be-FCC regulations require that owner's manuals make explicit that the privacy of cordless phone transmissions

254. See Loewy, supra note 214 , at 1244. 
is not ensured. ${ }^{255}$ Armed with this knowledge, cordless phone owners could manifest an expectation of privacy in their phone use by using the phone only in a deserted field or a thick-walled home, or by choosing not to use the phone at all.

New law enforcement technologies, on the other hand, provide citizens with no such warning. Because few people are aware that thermal imagers exist, they cannot take affirmative steps to shield their homes from a FLIR's intrusion. As the dissent stated in Cusumano, "I doubt that society is aware that heat signatures can be read with any greater accuracy than tea leaves."256 Criminals who grow marijuana indoors may be a bit further along on the learning curve (although the nearuniversal failure of marijuana growers to insulate their homes indicates that FLIR awareness is not yet widespread). In any event, it cannot be disputed that for some period of time following the introduction of a new technology, the public will be ignorant of its existence and its manner of use. It is during this period that police use of the technology presents a particular problem under the Katz framework.

The underlying source of this problem is that Katz's subjective prong asks whether the subject of a search has sought to protect her activities as private..$^{257}$ In the thermal imaging context, this frequently has devolved into the question of whether the defendant has made efforts to conceal or contain the heat generated by the indoor marijuana grow. ${ }^{258}$ Because most defendants have not taken such steps-in fact, most indoor marijuana cultivators actually vent heat outside their homes to maintain a proper growing temperature-courts have been reluctant to find that defendants have exhibited a subjective expectation of privacy in that heat. ${ }^{259}$

255. State v. DeLaurier, 488 A.2d 688, 694 (R.1. 1985).

256. United States v. Cusumano, 83 F.3d 1247, 1261 (10th Cir. 1995) (en banc) (McKay, J., dissenting); see also id. at 1259 n.17 (seeing "no reason why the government should be able to make inroads upon an individual's privacy by arrogating to itself hitherto unrecognized dimensions of privacy before subjective expectations can form").

257. Katz v. United States, 389 U.S. 347, 351 (1967).

258. See, e.g., United v. Myers, 46 F.3d 668, 669 (7th Cir.), cert. denied, 116 S. Ct. 213 (1995); United States v. Ford, 34 F.3d 992, 993 (11th Cir. 1994).

259. As already explained, these cases have misfocused their analysis on the heat being expelled, rather than on whether the defendants have manifested an expectation that their growing activities, the true subject of the search, will remain private. Of course, one could reasonably argue that the mere fact that indoor marijuana growers have moved their operations indoors and concealed the grows behind boarded windows in locked basements and garages is sufficient evidence that the defendants hope to keep their activities private. Yet the courts have been extremely reluctant to find Katz's subjective, but not objective, prong to be met.

Only one case has actually so found. In United States $v$. Ishmael, the Fifth Circuit rejected the government's argument that the defendants "failed" the subjective prong because they had vented the heat outside. Although the Ishmaels "did not-indeed, could not-take every precaution against the detection of the hydroponic laboratory," they had constructed the building housing the grow in great secrecy, away from prying eyes. 48 F.3d 850, 854 (5th Cir.), cert. denied, 116 S. Ct. 74 (1995). 
However, despite the Court's logic, people cannot be expected to manifest a subjective expectation of privacy in an activity they have no idea can be detected by others. Therefore, a reviewing court should consider the degree of public awareness surrounding a technology when conducting a Katz inquiry. This does not mean a court must perform the difficult and potentially arbitrary task of determining whether any "public awareness" line has been crossed; indeed, there is no bright line demarcating the point where technologies leave the land of the unknown and enter the realm of the known. What this criterion does mean is that a court should be more cautious in holding that a defendant has failed Katz's subjective prong when a new technology is at issue. ${ }^{260}$

This problem applies to Katz's objective prong as well. When a new search technology is not yet well understood (or known to exist), a citizen's expectation of privacy in data the technology can detect is inherently more reasonable than a demand for privacy in activities that well-known, commonly-used technologies can detect. Conversely, as the use of a technology becomes increasingly widespread, society will become less willing to recognize that an individual can reasonably expect to be free of intrusion from that technology. ${ }^{261}$ For example, even if a cordless phone user were unaware her calls could be intercepted, that expectation would not be one society would recognize as reasonable. ${ }^{262}$

FLIRs have been used by the police for only a few years, and their use remains far from common. In ten or twenty years, FLIR use may be so widespread that the courts justifiably could require individuals to take affirmative steps to mask their heat emissions in order to meet Katz's

The court concluded the defendants had exhibited a subjective expectation that their hydroponic laboratory would remain private. Id. In so holding, the Fifth Circuit rejected the position of the Seventh and Eleventh Circuits that voluntarily discharging heat equates to a lack of subjective privacy expectations. Myers, 46 F.3d at 669; Ford, 34 F.3d at 993 . In the end, however, this holding did not save the lshmaels: the Fifth Circuit proceeded to hold the Ishmaels' subjective privacy expectations unreasonable, and therefore found that no search had occurred. 1shmael, 48 F.3d at 856.

260. Of course, the constitutionality of a sophisticated yet publicly-recognized technology such as a telephone wiretap would still be evaluated under the other three "guideposts" presented in this Part.

261. For example, in Smith v. Maryland, the court held that the defendant could not have a reasonable expectation of privacy in the phone numbers he dialed because "[a]ll subscribers realize ... that the phone company has facilities for making permanent records of the numbers they dial" for billing purposes and to detect obscene calls. 442 U.S. 735, 742 (1979). If pen registers were not "regularly employed" by the phone company for such purposes, it is unlikely the Court would have upheld their use by the police. See id.

FLIRs currently have no such parallel, and probably never will. Unlike a phone company, which necessarily tracks monthly the phone numbers dialed by its subscribers, no public agency routinely monitors heat output from residential homes. Steele, supra note 6 , at 34 . This fact clearly makes the use of FLIRs a more troubling activity than police use of pen registers.

262. State v. DeLaurier, 488 A.2d 688, 694 (R.I. 1985). 
subjective prong. ${ }^{263}$ Similarly, in the future, society may be justified in refusing to recognize a subjective expectation of privacy as reasonable if an individual were to fail to take steps to shield heat-producing activities from scrutiny. Nevertheless, this "public acceptance" criteria is only one of several factors discussed herein that a court should consider when evaluating the Fourth Amendment implications of a new technology. The use of a highly intrusive device, disclosing sensitive and detailed information about the interior of a home, arguably violates the Fourth Amendment even if the existence and use of the technology is widely known.

FLIRs today, however, do not even present this problem. Given the minimal public awareness of these devices, and the resulting inability of law-abiding persons to take steps to protect their private heat-exuding activity from prying eyes, this criterion weighs heavily in favor of a finding that FLIR use today constitutes a search.

\section{The Degree of Intrusion}

The "intrusiveness" inquiry discussed in this Section cuts both ways. On the one hand, a search technique that is physically nonintrusive would appear preferable to one where the police were breaking down a door or running roughshod over private property. Similarly, a search that does not interfere with the subject's normal use of his property strikes us as preferable to a search that does so interfere. On the other hand, a search technique that never alerts the subject that a search is being conducted presents its own set of problems. While we all dislike our doors being kicked in, we might dislike it even more if we arrived home each day from work never knowing whether the police had conducted a thorough, yet physically nonintrusive, search of our property. As law-abiding citizens, the government would not be able to detect and subsequently confront us with any evidence of criminal activity-so we would never learn if we actually had been searched.

Although Katz rejects the idea that physical intrusion is an appropriate Fourth Amendment trigger, ${ }^{264}$ the Court has retreated somewhat from this holding in recent years. While the Court has not returned to the pre-Katz days when physical searching was the only issue the Court would consider, recent cases indicate that physical intrusion is playing an increasingly important role in determining whether a government search violates a reasonable expectation of privacy. ${ }^{265}$ In Ciraolo, for

263. This time might come sooner than we think, for both the technological development and the use of FLIRs are continuing to escalate rapidly. See Moore, supra note 6, at 835-36.

264. Katz v. United States, 389 U.S. 347, 353 (1967); see also supra notes 74-76 and accompanying text (describing the Court's acceptance of the idea that personal privacy could be violated even absent a physical trespass).

265. See Wilkins, supra note 235, at 1103-04. 
example, the Court discussed how the aerial observations of Ciraolo's curtilage occurred "in a physically nonintrusive manner." 266 In Dow Chemical, the intrusiveness of the EPA's aerial search was diminished because there was no "actual physical entry."267 In Florida v. Riley, the Court reiterated its Ciraolo holding that "the home and its curtilage are not necessarily protected from inspection that involves no physical invasion." 268 Likewise, the Court's decision in United States v. Place upholding dog sniffs for narcotics was based in part on the fact that the search did not require the luggage to be physically opened. ${ }^{269}$

The intrusiveness inquiry is not limited to the physical penetration of objects or spaces. Also relevant is the degree to which the government inspection interferes with the subject's normal use of the property. In Riley, the Court held that a helicopter flight over Riley's property was not a search because, among other factors, the helicopter caused " $\mathrm{o}$ undue noise, and no wind, dust, or threat of injury."270 Similarly, a dog sniff is less intrusive than a typical luggage search where an officer physically rummages through the contents of the luggage. ${ }^{271}$

The thermal imaging cases have seized on this language to assert that a FLIR search is unproblematic because it is not physically intrusive and does not interfere with the subject's normal use of his property. Penny-Feeney, for example, discussed how the observation was "physically nonintrusive" and, echoing Riley, caused "no undue noise, no wind, dust, or threat of injury."272 The courts of appeals upholding the warrantless use of FLIRs have made similar claims. ${ }^{273}$

Thermal imagers do not send beams or rays into the structures being observed, nor do FLIR searches cause immediate embarrassment or injury. In fact, the subject of a FLIR search is never aware she is being observed, unless she happens to see the helicopter hovering overhead. Yet it is important not to read too much into this fact. First, while an actual physical intrusion presents strong constitutional concerns, the absence of such an intrusion may not relieve those concerns. The Court has recognized, for instance, that government use of satellite technology

266. Califomia v. Ciraolo, 476 U.S. 207, 213 (1986).

267. Dow Chem. v. United States, 476 U.S. 227, 237 (1986).

268. 488 U.S. 445,449 (1989).

269. 462 U.S. 696,707 (1983).

270. Riley, 488 U.S. at 452.

271. Place, 462 U.S. at 707.

272. United States v. Penny-Feeney, 773 F. Supp. 220, 228 (D. Haw. 1991), aff'd on other grounds sub nom. United States v. Feeney, 984 F.2d 1053 (9th Cir. 1993).

273. See, e.g., United States v. 1shmael, 48 F.3d 850, 856 (5th Cir.) ("[S]ignificant [is the fact that] the officers never physically invaded the Ishmael's residential or commercial curtilage."), cert. denied, 116 S. Ct. 74 (1995); United States v. Ford, 34 F.3d 992, 996 (11th Cir. 1994) (thermal imager "cannot penetrate walls or windows"). 
to observe citizens might require a warrant ${ }^{274}$-yet a satellite located two hundred miles above the earth certainly presents no threat of physical invasion, no noise, and no possibility of injury.

Second, technological surveillance cannot be deemed nonintrusive simply because it operates from a distance. In fact, the ability of law enforcement officers to use satellites, wiretaps, and thermal imagers from a safe distance, without the suspect's knowledge, may make those technologies more unsettling to the average citizen. While the secrecy of technology-enhanced searches benefits police by allowing them to investigate conduct without alerting the suspect, such searches have high social costs. ${ }^{275}$ As discussed in Part IV, they cause law-abiding citizens to fear ongoing yet undetectable government surveillance. They chill the exercise of First Amendment rights, and reduce police accountability to the public. ${ }^{276}$

Given our dislike of physically intrusive searches and our possibly greater fear of physically nonintrusive searches, courts should be cautious about using intrusiveness as the key factor. In an era of increasingly sophisticated technologies in the arsenal of law enforcement, whether a "physical intrusion" has occurred becomes more tangential to the question of whether a Fourth Amendment search has taken place. This is particularly true when the object of the search is an intangible item such as heat rather than tangible property. Thermal imaging technology illustrates why the "physical intrusion" issue may become a question of diminished relevance as the courts are called upon to examine increasingly sophisticated search technologies. It also aptly illustrates how technology-enhanced searches provide a unique challenge to the law-abiding citizen attempting to preserve her spheres of privacy and personal autonomy.

\section{CONCLUSION}

When considering the intersection of technology and the Fourth Amendment, the real question is not whether the government will ever be permitted to use technological advances to combat crime. Indeed, technology shows great promise as a tool for helping law enforcement officers fight crime with greater effectiveness and reduced cost. Research efforts into such technologies should be actively encouraged.

What is truly at stake, however, is what constraints, if any, will be placed on such technologies to ensure that their use comports with the values and protections afforded by the Fourth Amendment.. To hold that an investigatory technique is not a search completely releases that

274. Dow Chem. v. United States, 476 U.S. 227, 238 (1986).

275. Steinberg, supra note 207, at 570-71.

276. See supra notes $223-226$ and accompanying text. 
technique from judicial scrutiny. In contrast, to recognize that a certain technique constitutes a search only means that law enforcement officials must first obtain a warrant before conducting such a search.

To require that a search be authorized by a warrant yields important benefits. It imposes a neutral and detached magistrate between a suspect and an officer in the field, ensuring that there is probable cause sufficient to justify the privacy invasion. It forces an officer to specify the information being sought, thereby allowing the magistrate to draw firm boundaries around the permissible scope of the search. It requires that a search be of limited duration.

A warrant requirement is particularly appropriate in the realm of technology-enhanced searches. Unbridled government discretion to conduct such searches provides law enforcement officials with chilling capabilities: to discover information, without physical invasion, about areas deserving of the highest Fourth Amendment protection; to learn about conduct often unrelated to the criminal activity under investigation; to search from afar, without alerting the suspect or the public at large, thereby reducing the demand for government accountability; and to search using techniques that the public cannot even imagine, and therefore cannot protect against. The potential for abuse is extraordinarily high.

Rather than impeding the government's ability to fight crime, the application of Fourth Amendment protection to technology-enhanced searches merely ensures that cutting-edge search techniques will take place openly and subject to public scrutiny. It also ensures that courts will not evaluate a new technology after it has been employed, when the evidence it has unearthed may be too enticing to forgo. With a beforethe-fact warrant application, the Fourth Amendment ramifications of a FLIR or similar technology can be evaluated in a judicial forum.

The Supreme Court will likely consider, in the near future, the Fourth Amendment implications of thermal imagers or soine similar device. This author hopes that the Court will not continue the post-Katz pattern of loosening Fourth Amendment guarantees when considering whether a technologically sophisticated surveillance technique constitutes a search. If the Court applies the very criteria it has enumerated in the post-Katz cases to evaluate technology such as thermal imagers, the Court should be compelled, at long last, to prevent further drifting from the core values underlying the Fourth Amendment. 